\title{
Effects of nicotine on homeostatic and hedonic components of food intake
}

\author{
Andrea Stojakovic',2, Enma P Espinosa1,3, Osman T Farhad' and Kabirullah Lutfy ${ }^{1}$ \\ 1Department of Pharmaceutical Sciences, College of Pharmacy, Western University of Health Sciences, Pomona, \\ California, USA \\ 2Mitochondrial Neurobiology and Therapeutics Laboratory, Mayo Clinic, Rochester, Minnesota, USA \\ ${ }^{3}$ Faculty of Medicine, School of Clinica Biochemistry, Pontifical Catholic University of Ecuador (PUCE), Quito, Ecuador
}

Correspondence should be addressed to K Lutfy

Email

klutfy@westernu.edu

\begin{abstract}
Chronic tobacco use leads to nicotine addiction that is characterized by exaggerated urges to use the drug despite the accompanying negative health and socioeconomic burdens. Interestingly, nicotine users are found to be leaner than the general population. Review of the existing literature revealed that nicotine affects energy homeostasis and food consumption via altering the activity of neurons containing orexigenic and anorexigenic peptides in the brain. Hypothalamus is one of the critical brain areas that regulates energy balance via the action of these neuropeptides. The equilibrium between these two groups of peptides can be shifted by nicotine leading to decreased food intake and weight loss. The aim of this article is to review the existing literature on the effect of nicotine on food intake and energy homeostasis and report on the changes that nicotine brings about in the level of these peptides and their receptors that may explain changes in food intake and body weight induced by nicotine. Furthermore, we review the effect of nicotine on the hedonic aspect of food intake. Finally, we discuss the involvement of different subtypes of nicotinic acetylcholine receptors in the regulatory action of nicotine on food intake and energy homeostasis.
\end{abstract}
Key Words
nicotine
- food intake
- obesity
- orexigenic peptides
- anorexigenic peptides (2017) 235, R13-R31

\section{Introduction}

Food intake is a complex physiological process necessary for the survival, and is affected by both homeostatic mechanisms as well as palatability of food. The homeostatic mechanisms involved in the regulation of food intake and energy expenditure include endocrine factors, such as hormones released from the pancreas and gastrointestinal neuroendocrine cells and adipose tissues, as well as gut/brain reflexes activated via the autonomic nervous system by peripheral signals from more than 20 regulatory hormones (Wren \& Bloom 2007, Kobeissy et al. 2008, Suzuki et al. 2010, Harwood 2012). Neural afferents and hormonal signals from the periphery are then integrated with neuronal circuits located in the central nervous system (CNS) implicated in the control of reward drive and mood to regulate appetite and control energy balance (Sam et al. 2012, Murray et al. 2014).

The hypothalamus along with the nucleus of the solitary tract (NST) in the brain stem, are the major brain regions responsible for the control of energy homeostasis, whereas the mesolimbic dopaminergic neurons and other brain areas, involved in motivation and emotion, are in charge of the hedonic aspects of food intake (Kelley \& Berridge 2002, Naleid et al. 2005). Hypothalamic neurons largely project to extrahypothalamic regions such as

Published by Bioscientifica Ltd. 
amygdala and the bed nucleus of stria terminalis (BNST), establishing connections between metabolism and eating behaviors (Nestler 2005, Rinaman 2010).

There are two major neuronal areas in the hypothalamus identified as regulators of food intake: the ventromedial hypothalamus ( $\mathrm{VMH})$, recognized as the appetite-suppressing center, and the lateral hypothalamus (LHA), involved in appetite stimulation (Anand \& Brobeck 1951). Subsequent studies have found the arcuate nucleus of hypothalamus (ARC) as another hypothalamic region with relevant functions in the control of food intake, since specific lesions performed in experimental animals at this level were found to promote food intake (Hamilton et al. 1976).

The ARC is located in the VMH and is characterized by the presence of two distinct, but intermingled neuronal populations, which have opposite effects on feeding behavior: the anorexigenic proopiomelanocortin (POMC) neurons and the orexigenic neuropeptide $\mathrm{Y}(\mathrm{NPY})$ /agoutirelated peptide (AgRP) neurons. The localization of these neurons as well as the rich innervations of the area, permit an easy access of the information coming from peripheral organs as well as from multiple parts of the CNS, making the POMC and NPY/AgRP neuronal groups integrating components of peripheral and central inputs to modulate feeding behavior (Gropp et al. 2005, Aponte et al. 2011).

Earlier studies based on stimulation of specific neuronal populations have demonstrated that direct activation of POMC neurons lead to suppression of food intake (Zhan et al. 2013). Later, it was shown that activation of POMC neurons suppresses appetite by causing the release of $\alpha$-melanocyte stimulating hormone $(\alpha-\mathrm{MSH})$, the endogenous melanocortin receptor agonist (Smart \& Low 2003); whereas, AgRP neurons inhibit POMC neurons possibly by directly blocking melanocortin receptors (Aponte et al. 2011).

Tobacco users have been reported to weigh less compared to their same sex- and age-matched nonsmokers (Albanes et al. 1987). In contrast, cessation of smoking has been associated with increased food intake, decrease in metabolic rate and concomitant weight gain (Stamford et al. 1986, Filozof et al. 2004). Indeed, in the first year after cigarette cessation, ex-smokers have been shown to gain on average about 10 pounds (AudrainMcGovern \& Benowitz 2011). Notably, this weight gain during abstinence represents an obstacle in smoking cessation because it serves as a motivating factor in former addicts to relapse to tobacco use (Donny et al. 2011).

The regulation of feeding and energy metabolism involves two interacting brain circuits: a homeostatic system centered in the hypothalamus and a hedonic system composed of the cortico-limbic-striatal circuits (Zoli \& Picciotto 2012). Several studies have demonstrated that nicotine reduces body weight by increasing energy expenditure and inhibiting food intake (Hofstetter et al. 1986, Perkins 1992), and that those effects are the result of the modulatory effect of nicotine on both metabolic processes and reward circuits (Blendy et al. 2005, Porter 2017). Studies performed in rodents have shown that nicotine exert pleasurable effects, similar, although weaker than cocaine and other addictive drugs (Risner \& Goldberg 1983). Furthermore, continuous subcutaneous administration of nicotine in obese rats under high-fat diet reduces food intake and suppresses further weight gain (Seoane-Collazo et al. 2014), indicating that these effects of nicotine are the result of the modulatory effects of nicotine on metabolic processes and reward circuits (Blendy et al. 2005, Porter 2017).

Nicotine exerts its effects on energy homeostasis via nicotinic acetylcholine receptors (nAChRs). These receptors are widely expressed throughout the central and peripheral nervous systems and particularly well positioned in the hypothalamus to alter the expression, secretion or function of neuropeptides that regulate appetite and food intake, thereby modulating energy homeostasis and feeding behavior. Nicotine has also been shown to change the levels of certain peptides in the periphery, by acting on nAChRs located in taste, visceral and nociceptive vagal afferent pathways, which also play a functional role in the ability of nicotine to alter food intake (Boucher et al. 2003, Mao et al. 2006, Dani \& Bertrand 2007, Oliveira-Maia et al. 2009).

Our goal is to describe the effects of nicotine in the functional features of the input, output and central integration systems that regulate the expression of the peptides present in the gastrointestinal tract, adipocytes and hypothalamus to regulate the homeostatic and hedonic aspects of food intake.

\section{Effects of nicotine on energy homeostasis}

Homeostasis in mammals is an intricate process aimed to maintain a delicate balance between food intake, energy expenditure and thermogenic activity. Most of the chemical reactions in the cell are pointed at making the energy in foods available to the various physiologic systems in the cell. All the energy in foods such as carbohydrates, fats and proteins, can be oxidized in the cells, and during this process, large amounts of energy are released with the ultimate goal of producing adenosine

Published by Bioscientifica Ltd. 
triphosphate (ATP) for the cells (Suzuki et al. 2010, Myers \& Olson 2012).

ATP is a labile compound with a structure characterized by the presence of two last phosphate radicals with high-energy bonds, consisting of about 12,000 calories under the usual physiologic conditions in the human body. Therefore, the removal of each radical in the body liberates about 12,000 calories of energy. If only one of those high-bond phosphates is lost, ATP is converted to adenosine diphosphate (ADP). When the second phosphate is liberated, ATP becomes adenosine monophosphate (AMP). The energy provided by ATP is not heat, but energy for the conduction of nerve impulses, for the active transport of molecules, to cause mechanical movement in the case of muscle or to concentrate solutes in the case of glandular secretion among others (De la Fuente et al. 2014).

Energy homeostasis is also dependent on thermogenic activity. Brown adipose tissue (BAT) is a specialized tissue critical for non-shivering or adaptive thermogenesis producing heat through mitochondrial uncoupling. BAT, and the newly described brite ('brown in white') adipose tissue (Harms \& Seale 2013), are crucial organs in facultative thermogenesis (acute response) and have a great plasticity to respond to long-term changes (e.g. cold acclimation (Harms \& Seale 2013, Vosselman et al. 2013). BAT mitochondria are distinct from their counterparts in other tissues in that ATP production is not their primary physiologic role. The inner mitochondrial membrane of BAT is loaded with the uncoupling protein-1 (UCP1). When activated, UCP1 allows protons in the intermembrane space to re-enter the mitochondrial matrix without generating ATP. As a consequence, heat is generated from the combustion of available substrates and is distributed to the rest of the body through the circulation (Vosselman et al. 2013, Contreras et al. 2017, Crichton et al. 2017, Porter 2017).

Thermogenesis by UCP1 in BAT is triggered by the release of noradrenaline from sympathetic nerve terminals regulated by the hypothalamus (Lowell \& Spiegelman 2000, Kelley \& Berridge 2002, Cano et al. 2003). Interestingly, it has been shown that acute or chronic nicotine exposure upregulates thermogenesis in BAT. Nicotine increases activity of lipoprotein lipase, improving lipid profile in rats by decreasing cholesterol and low-density lipoprotein (Chajek-Shaul et al. 1994) and inhibits fatty acid synthase in cell cultures of adipocytes (An et al. 2007). Moreover, microinjection of nicotine $(0.5 \mathrm{mg} / \mathrm{kg})$ into the preoptic area (POA) or the dorsomedial hypothalamus (DMH), but not the paraventricular nucleus (PVN) of rats, increases
BAT sympathetic nerve activity and BAT temperature through the activation of corticotropic releasing hormone/factor type 1 (CRH1/CRF1) receptors, indicating that one of the mechanisms for nicotine to affect energy homeostasis, is by eliciting the thermogenesis of BAT in the hypothalamus.

In this regard, it is noteworthy to state that nicotine elicits some of its actions via the endogenous opioid enkephalin (Berrendero et al. 2005), which has been implicated in beiging process, where white fat is converted to brown fat (Brestoff et al. 2015). Considering that brown fat is metabolically active and leads to greater energy utilization and thus body weight loss, it is possible that nicotine causes an increase in the expression of enkephalins in fat cells, inducing greater proportion of white to brown fat conversion. Indeed, nicotine has been shown to increase thermogenesis in BAT and also increase its mass via the adrenergic nervous system (WagerSrdar et al. 1984, Lupien \& Bray 1988, Yoshida et al. 1990, 1999). However, as stated above, enkephalin may be involved in this process. Thus, further studies are needed to assess if this action of nicotine is exerted via the endogenous enkephalins, and if this response mediates the ability of nicotine to reduce food intake and alter energy homeostasis. Additionally, it would be essential to explore whether this response is mediated via an action of nicotine on expression of enkephalin locally in white adipocytes. Furthermore, given that enkephalin is implicated in the rewarding action of nicotine, it is crucial to determine if enkephalin plays any functional role in the regulatory action of nicotine on hedonic aspect of food intake.

Adipose tissue plays a critical role in the maintenance of energy homeostasis through the secretion of adipokines, which interact with central as well as peripheral organs such as the brain, liver, pancreas and skeletal muscle to control carbohydrate metabolism, lipid metabolism, energy expenditure and feeding behavior (Scherer et al. 1995). Adiponectin, an adipokine secreted by the white adipose tissue (WAT), and present at high concentrations in the circulation, has been shown to be negatively correlated with body weight, body fat mass, degree of insulin resistance and weight reduction in obese individuals (Yamauchi et al. 2001, 2007, Kadowaki et al. 2006). Studies based on central administration of adiponectin in rodents, found that the animals presented significant weight and fat mass loss than their vehicle-treated counterparts, and that this decrease was a consequence of the increase in energy expenditure (stimulation of lipid oxidation by peripheral action on muscle and liver) independent of

Published by Bioscientifica Ltd 
food intake, consistent with centrally mediated effects (Qi et al. 2004) (Kubota et al. 2007). Likewise, studies based on receptor-binding assays to evaluate the effect of nicotine on the function of adipocytes, revealed the presence of nAChRs in adipose tissues, and that both shortor long-term exposure to nicotine stimulates the secretion of adiponectin into the culture medium, indicating that nicotine modulates food intake and body weight at least in part by an increase in the secretion of adiponectin through the activation of nAChRs (Liu et al. 2004). Clinical studies aimed to evaluate the changes of plasma adiponectin levels after smoking cessation, showed that the mean plasma adiponectin levels of the participants, when compared to the baseline, were significantly increased after 4 weeks of nicotine withdrawal (Won et al. 2014). Moreover, levels of adiponectin were directly related to weight gain after smoking cessation (Inoue et al. 2011), suggesting that nicotine regulates body weight by controlling adipose tissue homeostasis.

Nicotine has been shown to regulate many processes of energy balance by modulating the actions of AMPactivated protein kinase (AMPK). AMPK integrates hormonal and nutritive signals in peripheral organs and hypothalamus, thereby playing a major role in regulation of energy balance (Kahn et al. 2005). Activated in state of low energy balance, AMPK stimulates feeding behavior by modulating mitochondrial fatty acid oxidation in the hypothalamus, and its activity is regulated by changes in the expression of neuropeptides in the ARC (Minokoshi et al. 2004, Lopez et al. 2008). For example, the AgRP increases the activity of AMPK in the hypothalamus, whereas AMPK activity is inhibited by leptin in the ARC and PVN, as well as by insulin in multiple hypothalamic areas (Minokoshi et al. 2004). Likewise, changes in the activity of AMPK in the hypothalamus regulate the expression of these neuropeptides (Minokoshi et al. 2004).

Studies performed in rats showed that nicotine downregulates AMPK activity in the hypothalamus, and this effect mediates a decrease in food intake and BAT activation, as well as an increase in lipid oxidation. Conversely, genetic overactivation of AMPK in VMH can reverse nicotine-induced weight loss and normalize the mRNA levels of NPY, AgRP and POMC in ARC (Martinez de Morentin et al. 2012). Taken together, these data suggest that nicotine, by acting at peripheral and central levels, modulates food intake and energy homeostasis and controls the expression of several neuropeptides in the fat cells and hypothalamus to exert its regulatory action on food intake and energy expenditure.

\section{Effects of nicotine on central regulatory mechanisms of energy homeostasis}

Food intake is a process controlled by the CNS, and it is stimulated by sensations such as hunger, craving, pleasure and reward (Schwartz et al. 2000). The hypothalamus is the main brain region responsible for the control of food intake via the actions of certain neuropeptides that are secreted from two groups of neurons in ARC (Cone 2005). One neuronal population secretes orexigenic peptides, such as NPY and AgRP that stimulate appetite, whereas the other set of neurons express anorexigenic peptides, such as $\alpha-\mathrm{MSH}$, a product of POMC, and the cocaineand amphetamine-regulated transcript (CART), that suppresses appetite (Meister 2000, Lenard \& Berthoud 2008). Activation of NPY/AgRP-secreting neurons results in increased food intake, whereas stimulation of POMC/ CART containing neurons leads to decreased food intake. $\mathrm{AgRP}$ and $\alpha$-MSH act on melanocortin- 3 and 4 receptors (MC3R and MC4R) to regulate feeding behavior. The AgRP is an inverse agonist, while $\alpha$-MSH acts as an agonist of melanocortin receptors (MCR).

The neurons that secrete orexigenic and anorexigenic peptides predominantly project to other neurons located in the PVN, lateral hypothalamic area (LHA), perifornical area (PFA), ventromedial (VMN) and dorsomedial nuclei (DMN), establishing an anatomical and functional connection between these nuclei where the neuropeptides that they express can modulate eating behaviors (Schwartz et al. 2000, Ramos et al. 2005).

Smokers are reported to have reduced level of NPY, whereas smoking cessation is linked with increased levels of NPY (Hussain et al. 2012). In animal studies, mice chronically exposed to low-dose nicotine showed decreased NPY levels in the PVN (Chen et al. 2007) and ARC (Frankish et al. 1995), as well as reduced NPY receptor density in the hypothalamus (Kane et al. 2001), together with a nicotine-dependent increase in the activity of POMC neurons (Huang et al. 2011). This suggests that chronic administration of nicotine, by decreasing the level of NPY and upregulating the activity of POMC neurons, may negatively affect food intake and energy balance. However, further research is needed in this area to establish a causal relationship between weight gain and increased NPY levels in the hypothalamus following nicotine cessation.

Two other neuropeptides involved in regulation of feeding behavior are melanin-concentrating hormone (MCH) (Van Bockstaele et al. 2000) and hypocretin (also known as orexin), both of which are produced in the

Published by Bioscientifica Ltd. 
lateral hypothalamus (Skofitsch et al. 1985). It has been showed that the increase in either $\mathrm{MCH}$ or hypocretin stimulates food intake ( $\mathrm{Qu}$ et al. 1996, de Lecea et al. 1998). Interestingly, self-administration of nicotine in rats has been associated with increased expression of hypocretin receptor mRNA in ARC (LeSage et al. 2010). The modulation that nicotine exerts on the expression of peptides in ARC is more significant by considering that ARC also integrates the signal coming from peripheral organs and the rest of the CNS in order to execute the command for feeding behavior. For example, when the level of sugar rises in the blood circulation, it leads to the release of insulin from the pancreas, which not only increases the uptake of sugar by the muscle and liver, but also inhibits NPY/AgRP-containing neurons and stimulates POMC/CART-containing neurons in the ARC, leading to satiety. Similar effect is induced by leptin released from the fat cells (Schwartz et al. 2000). Thus, nicotine regulates energy homeostasis by influencing the secretion of insulin and leptin by regulating the expression of neuropeptides in specific hypothalamic nuclei.

Hypothalamic neurons also produce endocannabinoids, which play a critical role in maintaining a precise equilibrium between caloric intake and energy expenditure, storage and transport, factors that keep body weight stable over time (Valassi et al. 2008, Cristino et al. 2014).

The endocannabinoid system is composed of the cannabinoid receptors (CB1 and $\mathrm{CB} 2$ ), their endogenous ligands, like $\mathrm{N}$-arachidonoylethanolamine (AEA) and 2-arachidonoylglycerol (2-AG), the enzymes that produce and inactivate endocannabinoids, and endocannabinoid transporters (Piomelli 2003, Gardner 2005). Cannabinoid CB1 receptors are present in the ventral tegmental area (VTA) and the nucleus accumbens (NAc) and in several areas projecting to these two structures, including the prefrontal cortex, central amygdala and hippocampus, and they appear to play an important role in brain reinforcement/reward processes (Maldonado et al. 2006, Solinas et al. 2008).

Recent studies have implicated endocannabinoids in the pharmacological and behavioral effects of nicotine. For example, chronic nicotine injections increased endocannabinoids levels in the limbic forebrain and brainstem, but decreased levels in the hippocampus, striatum and cerebral cortex (Gonzalez et al. 2002), the same areas involved in the reinforcing/rewarding effects of addictive drugs (Koob et al. 1998). Moreover, a CB1 receptor antagonist, rimonabant, decreased nicotine self-administration and conditioned place preference
(CPP) in rats (Cohen et al. 2004, Le Foll \& Goldberg 2004), indicating that endocannabinoid signaling is involved in nicotine reinforcement and reward. Endocannabinoids stimulate appetite through different brain regions, such as limbic system (responsible for hedonic evaluation of food), hypothalamus, hindbrain, but also peripherally, at the level of adipose tissue and intestinal system (Fride et al. 2005). Blocking CB1 receptor in mice reduces appetite and lipogenesis in WAT (Cota et al. 2003). Chronic nicotine administration was shown to reduce body weight in wildtype, but not in $\mathrm{CB} 1^{-/-}$mice (Bura et al. 2010), suggesting that nicotine-mediated weight loss might be by the endocannabinoid system. More specific genetic approach in mice demonstrated that targeted deletion of CB1 receptor in cortical glutamatergic neurons reduces food intake (Bellocchio et al. 2010), suggesting that the decrease level of endocannabinoids in cortex observed with chronic nicotine administration (Gonzalez et al. 2002) might represent one of the mechanisms of nicotine-induced weight loss.

Interplay between rewarding effect of food and nicotine was also found in human studies where neuronal circuits activated by food rich in sugar and fat overlapped with those observed by smoking (Volkow et al. 2008). Moreover, absence of smoking increases the reward threshold for food (Kenny \& Markou 2006), suggesting that greater amount of highly rewarding food is sought in order to satisfy the rewarding effect previously achieved with nicotine (Spring et al. 2003). An intriguing proposal is that nicotine may hijack the reward circuit and devalue the motivational valence of food, thereby leading to decrease in food intake. However, further studies are needed to test this possibility.

Additionally, nicotine has been shown to activate the hypothalamic-pituitary-adrenal (HPA) axis, as shown by increases in the level of the stress hormone, i.e., cortisol in human/corticosterone in rodents (Rohleder \& Kirschbaum 2006). This process involves the release of CRH/CRF, which is known to exert anorexigenic effect (Glowa \& Gold 1991, Uehara et al. 1998). Thus, it is possible that nicotine, by activating the HPA axis and causing the release of CRH exerts its inhibitory effects on food intake. However, further studies are needed in this area to test this possibility and related research questions.

\section{Effects of nicotine on peripheral regulatory mechanisms of energy homeostasis}

The metabolic status of the body is also dependent on endocrine signals produced by the gastrointestinal

Published by Bioscientifica Ltd. 
system. Enteroendocrine cells of the gastrointestinal tract produce and release hormones to promote appetite (such as ghrelin) or satiety (e.g., cholecystokinin (CCK), glucagon-like peptide-1 (GLP-1), peptide tyrosine tyrosine (PYY) and serotonin). Administration of serotonin in the PVN, VMH and DMN of rats results in inhibition of food intake (Sleight et al. 1995, Leibowitz \& Alexander 1998). Ghrelin is an important hormone produced by the enteroendocrine cells of the gastric fundus and is released before a meal and its amount is reduced after a meal. Ghrelin regulates appetite by stimulating the AgRP- and NPY- containing neurons in the ARC as well as the NST, which in turn increases food intake (GilCampos et al. 2006).

Nicotine has been shown to alter mRNA expression and plasma levels of several gastrointestinal hormones (Chowdhury et al. 1990, Gomez et al. 1996). For example, smoking in human subjects acutely elevated the plasma level of ghrelin, an orexigenic hormone (Bouros et al. 2006). In another study, total plasma ghrelin levels were measured before and after smoking two cigarettes in nonsmokers and habitual smokers who underwent overnight fasting and also remained abstinent from smoking. It was found that the total plasma ghrelin level declined progressively in non-smokers, but not in smokers (Kokkinos et al. 2007). Given that the fasting plasma ghrelin level was similar between habitual smokers and non-smokers, the authors concluded that the decline in plasma ghrelin induced by acute nicotine may be blunted in smokers due to desensitization as a result of habitual nicotine use (Kokkinos et al. 2007). Furthermore, the plasma ghrelin levels decrease following two months of successful abstinence from nicotine (Lee et al. 2006), and that systemic elevation of plasma ghrelin occurred in acute but not in chronic smokers (Bouros et al. 2006), indicating that the desensitization induced by chronic nicotine exposure is overcome after nicotine cessation. Ghrelin was shown to increase food intake and this response was reduced by systemic administration of mecamylamine, a centrally acting nAChR antagonist, despite the animals were fasted overnight. In contrast, the peripherally acting nAChR antagonist, hexamethonium, failed to alter food intake in these animals, suggesting that the ability of ghrelin to increase food intake is mediated at least in part via the central nAChRs (Dickson et al. 2010). Additionally, fasting-induced food intake was reduced by mecamylamine in this study, suggesting that rewarding properties of food is mediated via the nAChRs, and this response might be reduced in smokers due to desensitization of $\mathrm{nAChR}$ as a result of chronic nicotine use, thereby giving a possible explanation for reduced food intake in smokers.

Leptin and insulin have overlapping intracellular signaling mechanisms and exert anorexigenic actions in the hypothalamus. Leptin, which is secreted predominantly from WAT, provides feedback information on the amount of fat stores to the ARC, PVN, LHA and the DMN of the hypothalamus, by acting on the long form of the leptin receptor (OB-Rb) (Meister 2000, Woods \& D'Alessio 2008). Leptin binding to OB-Rb in hypothalamus initiates tyrosine phosphorylation by janus tyrosine kinase 2 (JAK2). Phosphorylated JAK2 recruits and phosphorylates signal transducer and activator of transcription 3 (STAT3). The activated STAT3 dimerizes and translocate to the nucleus, stimulating gene transcription (Vaisse et al. 1996). Studies aimed to investigate the consequences of nicotine exposure during lactation, showed that offspring of lactating rats infused with nicotine ( $6 \mathrm{mg} / \mathrm{kg}$ per day), a dose that produces serum nicotine levels similar to those observed in typical smokers, results in lower expression of OB-R, JAK2 and phosphorylated STAT3 with higher suppressor of cytoskeleton signaling 3 (SOCS3) expression in the hypothalamus, indicating that nicotine induces leptin resistance via the same intracellular pathways as leptin (de Oliveira et al. 2010). Chronic administration of nicotine in rats was shown to increase expression of $\mathrm{Ob}-\mathrm{Rb}$ and leptin-binding sites within the hypothalamus of rats, while plasma leptin level remained reduced in WAT and BAT (Li \& Kane 2003). In a different study, chronic nicotine use in the form of nicotine gum or cigarette smoking caused an increase in circulating leptin level compared to control subjects, which was linked to the low body weight in nicotine users than control (Eliasson \& Smith 1999).

Insulin is also a critical regulator of energy homeostasis. As with leptin, insulin receptors are widely distributed in the brain, with higher concentrations in the ARC. In vivo and in vitro data have demonstrated that both leptin and insulin exert their metabolic functions by activating similar signaling pathways, including those that promote glucose uptake and glycogen storage through activation of JAK2, that in turn phosphorylates insulin receptor substrate 2 (IRS2) to activate phosphoinositide 3-kinase (PI3K), thereby increasing SOCS3 expression (Tanaka et al. 2009, Burgos-Ramos et al. 2011). Interestingly, there are reports that chronic nicotine administration

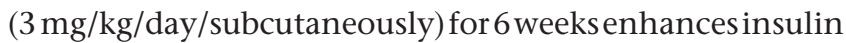
sensitivity in normal rats, by activating hypothalamic 
$\alpha 7-n A C h R-S T A T 3$ signaling pathway (Xu et al. 2012), the same pathway used by leptin to control appetite and body weight, as well as lipid and energy metabolism. Long-term oral nicotine administration reduces insulin resistance in obese rats (Liu et al. 2003). Furthermore, oral administration of $\alpha 7$-nAChR-selective agonist in leptinresistant $\mathrm{db} / \mathrm{db}$ obese mouse for 7 weeks prevented further weight gain, reduced food intake and improved plasma glucose level (Marrero et al. 2010). Likewise, nicotine infusion via osmotic minipumps showed differential effects on leptin levels, a decrease in the levels of leptin was observed after 4 days of nicotine administration, whereas an increase was observed when nicotine infusion was continued for 14 days compared with their respective controls (Arai et al. 2001). Interestingly, the increase in leptin levels was also dependent on the type of adipose tissue, being higher in omentum, retroperitoneal and epididymal WAT (Arai et al. 2001), suggesting that longterm nicotine administration induces tissue-selective leptin secretion.

With regard to insulin, it has been demonstrated that rats fed with high-fat diet and treated with daily subcutaneous nicotine injections for 8 days, show a significant reduction in body weight, food intake, insulin levels, improved serum lipid profile and reduced hepatic steatosis (Seoane-Collazo et al. 2014), indicating an improvement in insulin sensitivity. However, studies with chronic administration of nicotine using minipumps for 4 weeks in mice showed AMPK $\alpha$-dependent nicotine-induced insulin resistance (Wu et al. 2015). Clinical studies aimed to investigate the effects of chronic nicotine on leptin levels showed that leptin secretion was negatively correlated with chronic nicotine consumption and that leptin plasma concentration increases 8 weeks after cessation of smoking, in proportion to the gain in body weight (Eliasson \& Smith 1999). Overall, these studies suggest that chronic administration of nicotine may have positive outcome on metabolism in obesity and that the increase of leptin observed after chronic administration of nicotine, may be the result of the increase of plasma insulin concentration as a consequence of the insulin resistance induced by long-term tobacco smoking.

The report of the pathways by which nicotine acts to enhance insulin and leptin sensitivity gives a better perspective on the real effects of nicotine on energy homeostasis, since results from clinical and animal studies are inconsistent. Some clinical studies reported that nicotine infusion acutely impairs insulin sensitivity in type 2 diabetic patients and smokers but not in healthy subjects (Axelsson et al. 2001, Morgan et al. 2004). Longterm nicotine gum or nicotine patch replacement in previous smokers is associated with insulin resistance (Assali et al. 1999). These discrepancies between clinical and animal studies may be the result of difference in the duration and route of nicotine administration as well as the nutritional status of the subjects.

Leptin exerts its regulatory actions on food intake via homeostatic and reward mechanisms. During fasting, the levels of circulating leptin decreases, resulting in the activation of NPY- and AgRP-containing neurons and the secretion of the orexigenic peptides (NPY and AgRP) (Enriori et al. 2006, Ahima 2008), which induces feelings of hunger (Schwartz et al. 2000). In a fed state, an increase in leptin level stimulates the secretion of anorexigenic peptides, such as $\alpha$-MSH and CART from ARC that projects to the LHA and PFA, resulting in satiety sensation (Stanley et al. 1993, Ahima 2008).

Similarly to leptin, insulin acts in the ARC during feeding phase and its action is to inhibit NPY/AgRP- and stimulate POMC-containing neurons to prevent further food intake and contribute to the feeling of satiety (Plum et al. 2006). Moreover, it has been shown that intracerebroventricular administration of PI3K inhibitors in rodents, blocks the ability of leptin and insulin, but no other anorexigenic substances, to reduce food intake, indicating that both hormones utilize the same intracellular pathways and confirming the importance of their interaction in the maintenance of metabolic homeostasis (Niswender et al. 2003).

As with leptin and insulin, nicotine also regulates metabolic homeostasis at both peripheral and central levels, although the exact mechanisms have not yet been elucidated (Tweed et al. 2012). Clinical studies in populations with metabolic syndrome show that, independent of the weight, there are discrepancies in the distribution of adipose tissue. Some studies have reported that chronic smoking actually increased fat accumulation, which was accompanied with central obesity and insulin resistance (Barrett-Connor \& Khaw 1989). Similar studies showed that smokers have higher level of plasma triglycerides and lower level of high density lipoprotein cholesterol (HDL) (Facchini et al. 1992). Long-term smokers had higher waist-to-hip ratio compared to non-smokers, even though they were not heavier than non-smokers (Kim et al. 2012). Moreover, the waist-to-hip ratio correlated with increase in the number of cigarettes consumed (Clair et al. 2011). A positive correlation was found between body mass index (BMI) and increase in cigarette smoking in obese

Published by Bioscientifica Ltd. 
and morbidly obese subjects, suggesting that smoking might be more rewarding in this population (Chiolero et al. 2008). Besides, it has been reported that diabetic patients have lower rate of smoking cessation than non-diabetic smokers (Solberg et al. 2004, Gill et al. 2005). In conclusion, the effects of smoking on specific metabolic outcomes is somewhat complex, as smoking seems to contribute to weight loss in obese populations, while contributing to the development of central obesity and type-2 diabetes in lean smokers. Further research is needed in this area to define the underlying mechanism of this dichotomy.

\section{Role of nicotinic receptors in regulation of energy homeostasis}

Nicotine exerts its effects on energy homeostasis via nAChRs (Benowitz 2010). The nAChRs are widely expressed throughout the brain and particularly well positioned in the hypothalamus (Wada et al. 1989, O'Hara et al. 1998), to alter the function of neurons containing neuropeptides that regulate appetite and food intake, thereby modulating energy homeostasis and feeding behavior (Mineur et al. 2011). Nicotine has also been shown to change the level of certain peptides in the periphery that may also play a functional role in the ability of nicotine to alter food intake. The nAChRs are also found in brain areas involved in motivation and reward (Naude et al. 2016) and thus may be involved in the actions of nicotine on hedonic aspect of food intake (Lutter \& Nestler 2009).

The nAChRs are ligand-gated ion channels comprising five transmembrane subunits, which may be arranged in a $\alpha \beta$-combinations $(\alpha 2-\alpha 6$ and $\beta 2-\beta 4$; e.g., $\alpha 3 \beta 4^{*}$ containing nAChRs; the asterisk refers to one or more additional subunits that could be associated with the receptor), homomeric nAChRs $(\alpha 7-\alpha 9)$ and a heteromer $\alpha$-combination ( $\alpha 9$ with $\alpha 10$ ) (McGehee et al. 1995, Jones et al. 1999, Dani \& Bertrand 2007). An earlier in situ hybridization study showed that there are moderate-to-high levels of expression of $\alpha 4, \alpha 7$ and $\beta 2$ mRNA in the hypothalamus (Jo et al. 2002), suggesting that these nAChRs subunits might be predominately involved in the regulation of appetite control by nicotine. Depending on the dose and duration of nicotine exposure, nAChRs can either be desensitized or upregulated, thereby leading to different metabolic and behavioral effects by nicotine.
Control of feeding by nicotinic cholinergic $\alpha 3 \beta 4$ subunitcontaining receptors

Nicotine has been shown to reduce food intake and weight gain by modulating the function of melanocortin system through $\alpha 3 \beta 4^{*}$-containing nAChRs (Mineur et al. 2011). In particular, nicotine activates $\alpha 3 \beta 4^{*}$ nAChRs expressed on POMC neurons in the ARC nucleus of the hypothalamus (Mineur et al. 2011) that project to the PVN. Binding of nicotine to $\alpha 3 \beta 4^{*} \mathrm{nAChRs}$ leads to depolarization of POMCcontaining neurons in the $\mathrm{ARC}$, which in turn results in the release of $\alpha$-MSH (Cone 2005) and activation of MCRs located in PVN, thereby leading to reduced food intake (Mineur et al. 2011). Consistent with this notion, POMC knockout mice were shown to be resilient to the inhibitory effect of nicotine on food intake (Mineur et al. 2011).

\section{Control of feeding by nicotinic cholinergic $\beta 2$ subunit- containing receptors}

Recent studies have indicated that activation of $\beta 2 *$ containing $\mathrm{nAChRs}$ similar to $\alpha 3 \beta 4^{*} \mathrm{nAChRs}$ regulate the function of melanocortin system to reduce food intake and body weight gain in mice (Dezfuli et al. 2016). A relatively selective ligand of $\beta 2^{*}$-containing nAChRs sazetidine-A (SAZ-A) significantly reduced body weight and food intake in obese mice (Dezfuli et al. 2016). Specifically, chronic desensitization of $\beta 2 \mathrm{nAChRs}$ with continuous infusion of SAZ-A via subcutaneous osmotic pump resulted in reduction in body weight gain and food intake, and these changes were not observed in $\beta 2^{-/-}$and MCR4 $^{-/-}$mice (Dezfuli et al. 2016). These findings suggest that $\beta 2 \mathrm{nAChRs}$ might have an important role in regulation of food intake through melanocortin system. However, further studies are needed in this area to determine if the absence of $\beta 2$ subunit-containing nAChRs would cause alterations in the function of $\alpha 3 \beta 4^{*}$ containing nAChRs or vice versa and if that these variations could regulate food intake and body weight.

\section{Control of feeding by nicotinic cholinergic $\alpha \mathbf{4} \beta 2$ subunit- containing receptors}

Expression analysis within the hypothalamus has identified $\alpha 4 \beta 2$ subunits of nAChRs in LHA, ARC and PVN (Wada et al. 1989). Furthermore, $\alpha 4 \beta 2$ nAChRs are found on axons and cell bodies of dopaminergic neurons (Zoli et al. 2002), where it is involved in nicotine-induced dopamine release (Grady et al. 1992) and nicotine reward

Published by Bioscientifica Ltd. 
(McGranahan, 2011 \#1592). Activation of these receptors in the LHA appears to reduce food intake. Systemic, as well as local administration of $\alpha 4 \beta 2$ receptor antagonist, di-hydro- $\beta$-erythroidine (DH $\beta \mathrm{E})$ in LHA of fasted rats led to increased food intake in comparison to salinetreated controls (García et al. 2015). It is considered that modulatory action of endogenous $\mathrm{ACh}$ is mediated by $\alpha 4 \beta 2$ nAChRs, which was shown previously to affect the release of serotonin and dopamine in LHA (Meguid et al. 2000). This may be induced by a direct activation of $\alpha 4 \beta 2$ nAChRs in the LHA, as application of DHßE on hypothalamic slices inhibited nicotine-induced depolarization of POMC neurons (Huang et al. 2011). In another study, selective agonist of $\alpha 4 \beta 2$ receptor ((R,E)-5(2-pyrrolidin-3-ylvinyl)-pyrimidine) reduced food intake and body weight without affecting metabolic parameters such as glucose and triglyceride levels (Marrero et al. 2010). Replacement of nicotine with chronic administration of SAZ-A, a potent nAChR partial agonist (Xiao et al. 2006) that causes desensitization of $\alpha 4 \beta 2$ nAChRs, was shown to reverse the upregulation of the receptor induced by chronic nicotine administration. Besides, this drug, like nicotine, was able to reduce body weight in rats (Hussmann et al. 2014). Therefore, it may be that weightreducing effect of nicotine is mediated, at least in part, by its action on POMC neurons via the $\alpha 4 \beta 2$ nAChRs.

\section{Control of feeding by nicotinic cholinergic $\alpha 7$ subunit- containing receptors}

Despite the relevance of majority of nicotinic receptors being involved in control of feeding behaviors (Jo et al. 2002, Mineur et al. 2011), it is considered that the most prominent action of nicotine in control of feeding is accomplished through the activation of $\alpha 7$ nAChRs. Neurons containing $\alpha 7 \mathrm{nAChRs}$ are found in the ARC nucleus, VMH and DMN (Seguela et al. 1993). Apart from the hypothalamus, $\alpha 7$ nAChRs are expressed on dopaminergic neurons (Klink et al. 2001) and glutamatergic afferents projecting to the VTA (Jones \& Wonnacott 2004). Stimulation of $\alpha 7 \mathrm{nAChRs}$ was shown to suppress food intake via its actions in the hypothalamus (Jo et al. 2002). The $\alpha 7$ nAChRs are expressed on both POMC and NPY expressing neurons in the ARC nucleus and nicotine exerts its action on feeding behaviors by modulating the activity of these neurons. For example, an in vitro study showed that the effect of nicotine was reduced in isolated POMC neurons through the application of the $\alpha 7 \mathrm{nAChR}$ non-selective antagonist methyllycaconitine (MLA)
(Huang et al. 2011). On the other hand, levels of NPY were shown to be lower in smokers and also to be increased during nicotine cessation, suggesting that NPY has important role in control of food intake and body weight gain following smoking cessation (Hussain et al. 2012). In similar fashion, $\alpha 7 \mathrm{nAChR}$ antagonist MLA reduced the excitation of NPY by nicotine (Huang et al. 2011).

Aside from modulating the activity of neurons in the hypothalamus, $\alpha 7 \mathrm{nAChRs}$ have also been implicated in the release of neurotransmitters, such as -aminobutyric acid (GABA), glutamate, serotonin and dopamine. Nicotine administration can facilitate activation of GABA activity (Jo et al. 2002) and application of the $\alpha 7$ nAChRspecific antagonist ( $\alpha$-bungarotoxin) diminished this effect (Zhang \& Berg 2007), suggesting that the increase in GABAergic neuronal activity in the hypothalamus may mediate the anorexigenic effect of nicotine.

The role of $\alpha 7 \mathrm{nAChR}$ in modulating the dopamine release in connection to food intake is somewhat intricate. Taking into account that $\alpha 7 \mathrm{nAChRs}$ are widely expressed in the VTA, nicotine-induced activation of these receptors contributes to the release of glutamate (Schilstrom et al. 1998, 2000), which ultimately leads to increases in dopaminergic activity and release of dopamine in the NAc. In that regard, it is considered that $\alpha 7 \mathrm{nAChRs}$ contribute to the increased rewarding aspects of food (Schilstrom et al. 1998). On the other hand, elevated release of dopamine from dopaminergic projections to the LHA and VMH by nicotine is correlated with reduction in food intake (Meguid et al. 2000).

The $\alpha 7 \mathrm{nAChRs}$ are also found on serotonergic neurons (Galindo-Charles et al. 2008) and their activation by nicotine leads to the release of serotonin (Summers \& Giacobini 1995). Serotonin inhibits food intake (Waldbillig et al. 1981) and this is considered to be regulated via the inhibitory action of serotonin on NPY neurons, where it reduces the release of NPY (Dryden et al. 1996). Ultimately, nicotine-induced activation of nicotinic receptors increases the release of serotonin from extrinsic projections to the LHA, which contributes to appetite suppression (Jo et al. 2002).

\section{Nicotine and obesity-induce inflammation and insulin resistance}

Gene expression analysis studies in adipose tissue have revealed an increased expression of inflammatory markers in obese animals (Weisberg et al. 2003). Conversely, after weight loss in obese individuals, decreased expression

Published by Bioscientifica Ltd. 
(Clement et al. 2004) and secretion (Arvidsson et al. 2004) of pro-inflammatory components have been reported. The adipose tissue itself in obese individuals is thus a site of production of inflammatory markers (Wisse 2004). As in human and rodent models of obesity, a correlation was observed between the number of macrophages and the total amount of body fat, it was suggested that in obese subjects, the adipose tissue is actually in a proinflammatory state (Weisberg et al. 2003, Wisse 2004).

The increased accumulation of macrophages in WAT tissue may contribute to the enhanced systemic concentrations of pro-inflammatory cytokines in obesity. Not only tumor necrosis factor-alpha (TNF- $\alpha$ but also interleukin-6 (IL-6) (Lehrke et al. 2004) are known to interact directly with the insulin signaling cascade (Kershaw \& Flier 2004, Trayhurn \& Wood 2004, Wisse 2004), leading to the development of insulin resistance usually linked to obesity. Chronic cigarette smoking has been associated with elevated circulating levels of inflammatory cytokines, such as TNF- $\alpha$ and IL6 (Fernandez-Real et al. 2003, Ellingsgaard et al. 2008).

Aside from its central action, nicotine acting on a7 nAChRs expressed on immune cells may affect metabolic homeostasis. Recruitment of $\alpha 7$ nAChRs inhibits activation of pro-inflammatory nuclear factor-B (NF-B) signaling cascade in macrophages, that in turn reduces local inflammation (Pavlov et al. 2003). The anti-inflammatory action of nicotine, like that of the endogenous neurotransmitter acetylcholine (ACh), is due to the binding to and activation of $\alpha 7 \mathrm{nAChRs}$ on resident macrophages under the control of the 'cholinergic antiinflammatory pathway' (CAP) (Borovikova et al. 2000, Wang et al. 2003, Tracey 2007). The $\alpha 7$ nAChRs activation by ACh released from the efferent vagus nerve may be important in this regard (Borovikova et al. 2000). Clinical studies showed that the expression of $\alpha 7 \mathrm{nAChR}$ was reduced in fat cells isolated from subcutaneous adipose tissue of obese human subjects (Cancello et al. 2012). Moreover, oral application of specific $\alpha 7 \mathrm{nAChR}$ agonist in leptin-resistant $\mathrm{db} / \mathrm{db}$ obese mice reduced food intake and weight gain in these mice (Marrero et al. 2010). $\alpha 7$ nAChRs play a major role in the central and peripheral regulation of food intake and energy homeostasis. Furthermore, nicotine, acting on $\alpha 7 \mathrm{nAChRs}$ may inhibit the activation of pro-inflammatory cytokines, limiting the inflammatory state of obese smokers, and helping in reducing body weight. Although complex, activation of $\alpha 7 \mathrm{nAChRs}$ is critical in suppression of appetite and reduction of body weight gain.
In addition, studies have shown that higher circulating IL-6 promotes a shift in peptide production from glucagon toward glucagon-like peptide 1 (GLP-1), thus promoting functional beta-cell compensation to maintain proper insulin secretion and glucose homeostasis (Ellingsgaard et al. 2008). Moreover, knockout of IL-6 in mice or neutralization of IL-6 in wild-type mice fed with high-fat diet caused impairment of glucose homeostasis (Ellingsgaard et al. 2011), indicating that an adipose tissueendocrine-islet loop exists that could be regulated in some extent by nicotine-induced IL- 6 secretion, inducing metabolic adaptations that could result in weight loss in obese smokers. It does not explain, however, the presence of insulin resistance observed in chronic smokers. It may be a consequence of the desensitization that chronic nicotine exposure induces on $\alpha 7$ nAChRs, reducing circulating IL-6, therefore reducing GLP-1 secretion. It is accepted now that apart from its central action, nicotine activation of $\alpha 7 \mathrm{nAChRs}$ expressed on certain cells of the immune system may affect metabolic homeostasis. This is a new field that is being explored nowadays.

\section{Effects of nicotine on hedonic aspects of feeding}

Cigarette smoking constitutes a significant public health matter and is associated with increased risk of early morbidity and mortality. This becomes an even greater subject of concern if consider that nicotine, the primary psychoactive substance in tobacco smoke, activates mesolimbic dopaminergic signaling pathways, which are important component of the reward system in the brain and is implicated in the development of addiction (Nestler 2005, Criscitelli \& Avena 2016). Nicotine also plays an important role in the modulation of food intake and metabolism. As with nicotine, highly palatable foods are also capable of altering dopamine release within this system, giving place to addictive responses in susceptible individuals (Zoli \& Picciotto 2012).

In support of this notion, there is a large body of evidence showing that motivational aspects of certain foods and drugs of abuse share similar reward pathways. For example, nicotine mediates its rewarding effect by directly stimulating dopaminergic transmission from VTA to NAc and food produces similar responses within the mesolimbic system (Nestler 2005).

Preclinical and clinical studies demonstrate that despite strong commitment of smokers to stop smoking,

Published by Bioscientifica Ltd 
the addictive properties of nicotine makes cessation from smoking too difficult (Goodman et al. 2008). For example, out of $70 \%$ smokers who try to quit smoking, only $7 \%$ were reported to achieve long-term abstinence from tobacco use (Goodman et al. 2008). Furthermore, among human population, nicotine mechanisms of addiction seem to be related with the concentration and distribution of adipose tissue, as individuals with higher BMI smoke more cigarettes per day than non-smokers (Rupprecht et al. 2015). Moreover, results obtained from human studies showed that nicotine was less rewarding to obese non-deprived smokers, as measured by percentage of total puffs taken from cigarettes with normal nicotine content (Blendy et al. 2005). On the other hand, obese participants were experiencing higher hedonic effect with cigarettes that were containing lower content of nicotine (Rupprecht et al. 2015), suggesting that obese people might be more prone to smoking, while increased smoking in obese population might be related to lower rewarding effect of nicotine (Rupprecht et al. 2015). Studies performed in rodents displayed similar results. Mice fed a high-fat diet failed to display preference to nicotine in CPP paradigm indicating that, consumption of palatable food can alter normal reward processing (Blendy et al. 2005, Kenny 2011), which may explain the difference in smoking habits between lean and obese human population.

Regulation of food intake by dopamine takes place in the hypothalamus through the action of dopamine on its receptors, D1 and D2 receptors (Ramos et al. 2005). In the hypothalamus, release of dopamine is associated with increased duration of food intake. Free-feeding rats treated with repeated systemic administration of D1 agonist (SKF 38393) exhibit decrease food intake, while D2 receptor agonist (+)-4-propyl-9-hydroxynaphthoxazine (PHNO) has opposite effects in the same animal population (Rusk $\&$ Cooper 1989). Outside the hypothalamus, activation of D1 expressing neurons in the NAc has been reported to stimulate feeding behavior (Zhu et al. 2016). Released ACh from the cholinergic interneurons in the NAc binds to nAChRs and influences the release of dopamine and thus reward processing (Mark et al. 2011). Both acute and chronic nicotine treatment modulates the hedonic aspects of food intake by increasing the release of dopamine from the ventral and dorsal striatum, through activation of nAChRs, such as $\alpha 4^{*}$ and $\alpha 6^{*}$ containing nAChRs (Grady et al. 2007, De Biasi \& Dani 2011). Furthermore, chronic long-term sucrose intake increased $\alpha 4 \beta 2^{*}$ while decreases $\alpha 6 \beta 2$ nAChRs in the NAc (Shariff et al. 2016).
Administration of mecamylamine suppressed sucrose intake (Shariff et al. 2016), pavlovian incentive motivation (Ostlund et al. 2014) and operant self-administration of sucrose at higher doses (Ford et al. 2009).

Projections from the shell of NAc to the lateral hypothalamus and striatopallidal system, which are regulated by opioids, endocannabinoids and dopaminergic input, respond and mediate the sensory properties of palatable food as well as that of drugs of abuse, such as nicotine (Kenny 2011a,b). Consumption of palatable food and drugs of abuse also induces changes in striatal reward circuits through the action of hormones and neuropeptides. Hypocretin and $\mathrm{MCH}$ are two neuropeptides that not only regulate food intake, but also mediate the rewarding properties of drugs of abuse by modulating the function of mesolimbic dopaminergic neurons (Zheng et al. 2007, Chung et al. 2009). The MCH receptors are expressed in the NAc, activation of which stimulates feeding behaviors (Georgescu et al. 2005). On the other hand, inhibition of $\mathrm{MCH}$ receptors in the NAc diminished cocaine-induced CPP (Chung et al. 2009). Likewise, alcohol CPP was decreased in MCH1-R knockout mice (Karlsson et al. 2016), suggesting that $\mathrm{MCH}$ signaling might also be involved in the rewarding effect of nicotine. Blockade of hypocretin receptor in insula reduces nicotine self-administration in rats (Hollander et al. 2008).

Nicotine-induced CPP as well as nicotine withdrawal were attenuated in mice lacking the preproenkephalin gene compared to their wild-type controls (Berrendero et al. 2005), suggesting that opioids derived from proenkephalin are involved in the rewarding effect of nicotine as well as nicotine dependence. The significance of POMC signaling on nicotine reward was shown in an earlier study, where mice lacking beta-endorphin displayed reduced nicotineinduced CPP (Trigo et al. 2009). Mice lacking betaendorphin had higher body weight compared to their wild-type controls (Rubinstein et al. 1996), suggesting that beta-endorphin may also be involved in energy homeostasis and in the ability of nicotine to reduce body weight. Considering that mice lacking POMC exhibited blunted response to nicotine-induced reduction of food intake (Mineur et al. 2011) and that beta-endorphin is derived from POMC, further research is needed to assess the role of beta-endorphin in the ability of nicotine to reduce body weight and energy homeostasis.

Nicotine administration was shown to reduce NPY immunoreactivity in the shell of NAc, PVN and ARC (Kotagale et al. 2014). Co-administration of NPY Y1 receptor potentiated the inhibitory effect of agmatine
Published by Bioscientifica Ltd 
on nicotine-induced CPP, suggesting that NPY signaling negatively affects nicotine-mediated reward processing (Kotagale et al. 2014). However, further research is needed to define the underlying mechanism of the regulatory action of NPY on nicotine reward and whether this is a direct effect of NPY or a combination of agmatine and NPY.

In addition to neuropeptides, hormonal regulator of appetite such as ghrelin increases motivation for food and drug intake by activating cholinergic and dopaminergic systems (Jerlhag et al. 2006, Skibicka et al. 2011). Ghrelin activates dopaminergic neurons of the VTA via cholinergic input, leading to dopamine overflow in the NAc, suggesting that ghrelin may regulate motivational aspect of feeding behavior (Jerlhag et al. 2006).

Leptin receptors are expressed on dopaminergic neurons (Figlewicz etal.2003) and leptin inhibits appetite by regulating the function of the mesolimbic neurons (Fulton et al. 2006). More specifically, leptin attenuates activation of striatal reward system, as it was shown that leptin replacement reduces self-reported liking of food in humans (Farooqi et al. 2007). Infusion of leptin directly into the VTA inhibits activation of dopamine neurons (Hommel et al. 2006) and decreases brain reward function in rats (Bruijnzeel et al. 2011). Mice fed a high-fat diet had reduced expression of leptin receptor in the VTA, and also did not exhibit nicotine CPP (Blendy et al. 2005), suggesting that increased leptin level in obesity attenuates reward processing in the brain via an action on the activity of dopaminergic neurons.

Insulin is another hormone that regulates energy homeostasis. Insulin receptors are found to be expressed in the VTA and NAc, suggesting that insulin is involved in the regulation of food intake by an action on dopaminergic neurons (Zahniser et al. 1984, Figlewicz et al. 2003). In particular, insulin administration in the VTA decreases rewarding effect of palatable food (Figlewicz et al. 2008) by increasing reuptake of dopamine through the dopamine transporter (Mebel et al. 2012). In contrast, inactivation of insulin receptor in dopaminergic neurons leads to hyperphagia and weight gain (Konner et al. 2011). Diabetic rats are shown to have reduced level of dopamine in midbrain and striatum (Murzi et al. 1996), and streptozotocin-induced hypoinsulinemic rats showed increased nicotine self-administration (O'Dell et al. 2014). Similarly, insulin-resistant rats fed a high-fat diet showed enhanced nicotine preference in the CPP paradigm (Richardson et al. 2014). This disrupted dopaminemediated reward transmission induced by impaired insulin signaling, may explain higher preference for nicotine intake in obese smokers. It also suggests that higher self-administration of nicotine in diabetic rats may be due to reduced nicotine reward in these rats compared to controls. However, further studies are needed to determine whether the differences are as a result of species differences (mouse vs rat), treatment (high fat vs streptozotocin) and/or experimental procedure (CPP vs drug self-administration paradigm).

Nicotine has been shown to serve as a gateway drug to promote the use of other addictive drugs, such as alcohol and cocaine (Huang et al. 2013). Nicotine also appears to affect the reward threshold for natural reinforcing agents, suggesting common mechanism for the gateway action of nicotine. However, the effect of nicotine on these reinforcers is different depending on the duration of nicotine administration and whether animals are exposed to sucrose or fat, and even the content of fat in food is important in this regard. Acute nicotine enhances rewarding effect of palatable food. For example, mice with acute exposure to nicotine were found to have higher brake-point for sucrose in the operant conditioning paradigm (Brunzell et al. 2006). Similarly, using CPP paradigm, Buffalari and coworkers showed that animals conditioned with cocaine or sucrose and tested for place preference after a single nicotine challenge exhibited greater preference for the sucrose- as well as cocainepaired compartment, showing that nicotine increased the motivational valence of contextual cue associated with cocaine as well as sucrose (Buffalari et al. 2014). Animals fed on high-fat diet and exposed to chronic nicotine tend to maintain or even increase their body weight in comparison to their regular low-fat diet-fed controls (Wellman et al. 1986, Mangubat et al. 2012). Another similar study showed that chronic peripheral administration of nicotine induces reduction of body weight and increases BAT thermogenesis in groups of rats fed either high or low-fat diet, suggesting that the reinforcing effect of nicotine disappears after chronic exposure, but may be restored after the cessation of nicotine use (Parker \& Doucet 1995).

\section{Summary and conclusions}

The regulation of feeding and metabolism by nicotine appears somewhat complex, mainly because it acts at different levels, both centrally and peripherally, to regulate multiple hormones and neuropeptides and their receptors to modify energy expenditure and feeding behavior.

Adipose tissue has a crucial role in metabolic homeostasis and is one of the targets of nicotine's action. On the one hand, nicotine increases energy expenditure

Published by Bioscientifica Ltd 
and thermogenesis by enhancing the expression of the mitochondrial carrier proteins UCP1 mRNA in BAT (Chen et al. 2006, Zoli \& Picciotto 2012). On the other hand, nicotine stimulates the secretion of adiponectin and leptin (hormones with autocrine, paracrine and endocrine functions) from WAT, which lead to reduced food intake and increased metabolism, both effects observed in tobacco smokers. Interestingly, experimental studies in rodents suggest that adiponectin increases insulin sensitivity in peripheral tissues (Matsuzawa 2006), whereas human studies report that long-term exposure to nicotine induces changes in fat distribution associated with insulin resistance (Wu et al. 2015). Further studies show that resident macrophages located in WAT express $7 \alpha \mathrm{nAChR}$, and that once activated by nicotine, they inhibit the secretion of pro-inflammatory cytokines. This could be the cause of the weight loss observed in obese smokers, who present a mild state of chronic inflammation. However, it has also been shown that long-term exposure to nicotine desensitizes its receptor, increasing the secretion of cytokines, a situation that may lead to fat redistribution, insulin resistance and worsening of the metabolic state.

Nicotine exerts its modulatory effects by binding to the nAChRs, which are widely distributed in the ARC nucleus of hypothalamus, allowing the regulation of the signals that arrive from the periphery to the brain, leading to reduced food intake and increase energy output. At central levels, nicotine has been shown to stimulate the orexigenic neurons NPY/AgRP and inhibit the anorexigenic POMC-containing neurons, probably through the activation of $\alpha-7$ and $\alpha 3 \beta 4$ containing nicotinic receptors which in turn activate the AMPK signaling pathways. Hence nicotine, by affecting feeding behavior, could affect the storage of energy, which in turn modulates the secretion of hormones, peptides and neurotransmitters that ultimately would induce changes in energy expenditure and metabolic homeostasis.

Finally, nicotine, by stimulating dopaminergic transmission within the mesolimbic system, stimulates the reward system in the same way that recreational drugs such as cocaine does, making it difficult for smokers to quit using tobacco. Nicotine exerts this effect by acting upon different subtypes of nAChRs, like $\alpha 4 \beta 2^{*}$ and $\alpha 6 \beta 2$ nAChRs, opening a new field of study about addiction and smoking tobacco and other nicotine-containing products.

In spite of the evidence accumulated with regard to the action of nicotine, further studies are needed to delineate the exact mechanism of nicotine-induced changes in energy expenditure and feeding behavior. The results of these studies are expected to provide useful basic science information that may lay the foundation for the development of novel pharmacotherapy to treat nicotine as well as food addiction and obesity.

\section{Declaration of interest}

The authors declare that there is no conflict of interest that could be perceived as prejudicing the impartiality of this review.

\section{Funding}

This work was supported by a Tobacco Related Disease Research Program (TRDRP 24RT-0023) to K L. A S and E P E were supported in part by a SBIR Phase II Grant HHSN275201500005C. OF was supported by the Department of Pharmaceutical Sciences, College of Pharmacy at Western University of Health Sciences (Pomona, CA).

\section{References}

Ahima RS 2008 Revisiting leptin's role in obesity and weight loss. Journal of Clinical Investigation 118 2380-2383. (doi:10.1172/JCI36284)

Albanes D, Jones DY, Micozzi MS \& Mattson ME 1987 Associations between smoking and body weight in the US population: analysis of NHANES II. American Journal of Public Health 77 439-444. (doi:10.2105/ajph.77.4.439)

An Z, Wang H, Song P, Zhang M, Geng X \& Zou MH 2007 Nicotineinduced activation of AMP-activated protein kinase inhibits fatty acid synthase in 3T3L1 adipocytes: a role for oxidant stress. Journal of Biological Chemistry 282 26793-26801. (doi:10.1074/jbc.M703701200)

Anand BK \& Brobeck JR 1951 Localization of a feeding center in the hypothalamus of the rat. Proceedings of the Society for Experimental Biology and Medicine 77 323-324. (doi:10.3181/00379727-77-18766)

Aponte Y, Atasoy D \& Sternson SM 2011 AGRP neurons are sufficient to orchestrate feeding behavior rapidly and without training. Nature Neuroscience 14 351-355. (doi:10.1038/nn.2739)

Arai K, Kim K, Kaneko K, Iketani M, Otagiri A, Yamauchi N \& Shibasaki T 2001 Nicotine infusion alters leptin and uncoupling protein $1 \mathrm{mRNA}$ expression in adipose tissues of rats. American Journal of Physiology Endocrinology and Metabolism 280 E867.

Arvidsson E, Viguerie N, Andersson I, Verdich C, Langin D \& Arner P 2004 Effects of different hypocaloric diets on protein secretion from adipose tissue of obese women. Diabetes 53 1966-1971. (doi:10.2337/ diabetes.53.8.1966)

Assali AR, Beigel Y, Schreibman R, Shafer Z \& Fainaru M 1999 Weight gain and insulin resistance during nicotine replacement therapy. Clinical Cardiology 22 357-360. (doi:10.1002/clc.4960220512)

Audrain-McGovern J \& Benowitz NL 2011 Cigarette smoking, nicotine, and body weight. Clinical Pharmacology and Therapeutics 90 164-168. (doi:10.1038/clpt.2011.105)

Axelsson T, Jansson PA, Smith U \& Eliasson B 2001 Nicotine infusion acutely impairs insulin sensitivity in type 2 diabetic patients but not in healthy subjects. Journal of Internal Medicine 249 539-544. (doi:10.1046/j.1365-2796.2001.00840.x)

Barrett-Connor E \& Khaw KT 1989 Cigarette smoking and increased central adiposity. Annals of Internal Medicine 111 783-787. (doi:10.7326/0003-4819-111-10-783)

Bellocchio L, Lafenetre P, Cannich A, Cota D, Puente N, Grandes P, Chaouloff F, Piazza PV \& Marsicano G 2010 Bimodal control of stimulated food intake by the endocannabinoid system. Nature Neuroscience 13 281-283. (doi:10.1038/nn.2494) 
Benowitz NL 2010 Nicotine addiction. New England Journal of Medicine 362 2295-2303. (doi:10.1056/NEJMra0809890)

Berrendero F, Mendizabal V, Robledo P, Galeote L, Bilkei-Gorzo A, Zimmer A \& Maldonado R 2005 Nicotine-induced antinociception, rewarding effects, and physical dependence are decreased in mice lacking the preproenkephalin gene. Journal of Neuroscience $\mathbf{2 5}$ 1103-1112. (doi:10.1523/JNEUROSCI.3008-04.2005)

Blendy JA, Strasser A, Walters CL, Perkins KA, Patterson F, Berkowitz R \& Lerman C 2005 Reduced nicotine reward in obesity: crosscomparison in human and mouse. Psychopharmacology 180 306-315. (doi:10.1007/s00213-005-2167-9)

Borovikova LV, Ivanova S, Zhang M, Yang H, Botchkina GI, Watkins LR, Wang H, Abumrad N, Eaton JW \& Tracey KJ 2000 Vagus nerve stimulation attenuates the systemic inflammatory response to endotoxin. Nature 405 458-462. (doi:10.1038/35013070)

Boucher Y, Simons C, Cuellar J, Jung S-W, Carstens M \& Carstens E 2003 Activation of brain stem neurons by irritant chemical stimulation of the throat assessed by c-fos immunohistochemistry. Experimental Brain Research 148 211-218. (doi:10.1007/s00221-002-1308-1)

Bouros D, Tzouvelekis A, Anevlavis S, Doris M, Tryfon S, Froudarakis M, Zournatzi V \& Kukuvitis A 2006 Smoking acutely increases plasma ghrelin concentrations. Clinical Chemistry 52 777-778. (doi:10.1373/ clinchem.2005.065243)

Brestoff JR, Kim BS, Saenz SA, Stine RR, Monticelli LA, Sonnenberg GF, Thome JJ, Farber DL, Lutfy K, Seale P, et al. 2015 Group 2 innate lymphoid cells promote beiging of white adipose tissue and limit obesity. Nature 519 242-246. (doi:10.1038/nature14115)

Bruijnzeel AW, Corrie LW, Rogers JA \& Yamada H 2011 Effects of insulin and leptin in the ventral tegmental area and arcuate hypothalamic nucleus on food intake and brain reward function in female rats. Behavioural Brain Research 219 254-264. (doi:10.1016/j.bbr.2011.01.020)

Brunzell DH, Chang JR, Schneider B, Olausson P, Taylor JR \& Picciotto MR 2006 Beta2-Subunit-containing nicotinic acetylcholine receptors are involved in nicotine-induced increases in conditioned reinforcement but not progressive ratio responding for food in C57BL/6 mice. Psychopharmacology 184 328-338. (doi:10.1007/s00213-005-0099-z)

Buffalari DM, Marfo NY, Smith TT, Levin ME, Weaver MT, Thiels E, Sved AF \& Donny EC 2014 Nicotine enhances the expression of a sucrose or cocaine conditioned place preference in adult male rats. Pharmacology Biochemistry and Behavior 124 320-325. (doi:10.1016/j. pbb.2014.06.013)

Bura SA, Burokas A, Martin-Garcia E \& Maldonado R 2010 Effects of chronic nicotine on food intake and anxiety-like behaviour in $\mathrm{CB}(1)$ knockout mice. European Neuropsychopharmacology 20 369-378. (doi:10.1016/j.euroneuro.2010.02.003)

Burgos-Ramos E, Chowen JA, Arilla-Ferreiro E, Canelles S, Argente J \& Barrios V 2011 Chronic central leptin infusion modifies the response to acute central insulin injection by reducing the interaction of the insulin receptor with IRS2 and increasing its association with SOCS3. Journal of Neurochemistry 117 175-185. (doi:10.1111/j.14714159.2011.07191.x)

Cancello R, Zulian A, Maestrini S, Mencarelli M, Della Barba A, Invitti C, Liuzzi A \& Di Blasio AM 2012 The nicotinic acetylcholine receptor alpha7 in subcutaneous mature adipocytes: downregulation in human obesity and modulation by diet-induced weight loss. International Journal of Obesity 36 1552-1557. (doi:10.1038/ijo.2011.275)

Cano G, Passerin AM, Schiltz JC, Card JP, Morrison SF \& Sved AF 2003 Anatomical substrates for the central control of sympathetic outflow to interscapular adipose tissue during cold exposure. Journal of Comparative Neurology 460 303-326. (doi:10.1002/cne.10643)

Chajek-Shaul T, Scherer G, Barash V, Shiloni E, Caine Y, Stein O \& Stein Y 1994 Metabolic effects of nicotine on human adipose tissue in organ culture. Clinical Investigation 72 94-99. (doi:10.1007/BF00184583)

Chen H, Hansen MJ, Jones JE, Vlahos R, Bozinovski S, Anderson GP \& Morris MJ 2006 Cigarette smoke exposure reprograms the hypothalamic neuropeptide $\mathrm{Y}$ axis to promote weight loss. American
Journal of Respiratory and Critical Care Medicine 173 1248-1254. (doi:10.1164/rccm.200506-977OC)

Chen H, Hansen MJ, Jones JE, Vlahos R, Bozinovski S, Anderson GP \& Morris MJ 2007 Regulation of hypothalamic NPY by diet and smoking. Peptides 28 384-389. (doi:10.1016/j.peptides.2006.07.034)

Chiolero A, Faeh D, Paccaud F \& Cornuz J 2008 Consequences of smoking for body weight, body fat distribution, and insulin resistance. American Journal of Clinical Nutrition 87 801-809.

Chowdhury P, Hosotani R, Chang L \& Rayford PL 1990 Metabolic and pathologic effects of nicotine on gastrointestinal tract and pancreas of rats. Pancreas 5 222-229. (doi:10.1097/00006676-199003000-00016)

Chung S, Hopf FW, Nagasaki H, Li CY, Belluzzi JD, Bonci A \& Civelli O 2009 The melanin-concentrating hormone system modulates cocaine reward. PNAS 106 6772-6777. (doi:10.1073/pnas.0811331106)

Clair C, Chiolero A, Faeh D, Cornuz J, Marques-Vidal P, Paccaud F, Mooser V, Waeber G \& Vollenweider P 2011 Dose-dependent positive association between cigarette smoking, abdominal obesity and body fat: cross-sectional data from a population-based survey. BMC Public Health 11 23. (doi:10.1186/1471-2458-11-23)

Clement K, Viguerie N, Poitou C, Carette C, Pelloux V, Curat CA, Sicard A, Rome S, Benis A, Zucker JD, et al. 2004 Weight loss regulates inflammation-related genes in white adipose tissue of obese subjects. FASEB Journal 18 1657-1669. (doi:10.1096/fj.04-2204com)

Cohen C, Perrault G, Griebel G \& Soubrie P 2004 Nicotine-associated cues maintain nicotine-seeking behavior in rats several weeks after nicotine withdrawal: reversal by the cannabinoid (CB1) receptor antagonist, rimonabant (SR141716). Neuropsychopharmacology 30 145-155. (doi:10.1038/sj.npp.1300541)

Cone RD 2005 Anatomy and regulation of the central melanocortin system. Nature Neuroscience 8 571-578. (doi:10.1038/nn1455)

Contreras C, Nogueiras R, Diéguez C, Rahmouni K \& López M 2017 Traveling from the hypothalamus to the adipose tissue: the thermogenic pathway. Redox Biology 12 854-863. (doi:10.1016/j. redox.2017.04.019)

Cota D, Marsicano G, Tschop M, Grubler Y, Flachskamm C, Schubert M, Auer D, Yassouridis A, Thone-Reineke C, Ortmann S, et al. 2003 The endogenous cannabinoid system affects energy balance via central orexigenic drive and peripheral lipogenesis. Journal of Clinical Investigation 112 423-431. (doi:10.1172/JCI17725)

Crichton PG, Lee Y \& Kunji ERS 2017 The molecular features of uncoupling protein 1 support a conventional mitochondrial carrier-like mechanism. Biochimie 134 35-50. (doi:10.1016/j. biochi.2016.12.016)

Criscitelli K \& Avena NM 2016 The neurobiological and behavioral overlaps of nicotine and food addiction. Preventive Medicine 92 82-89. (doi:10.1016/j.ypmed.2016.08.009)

Cristino L, Becker T, Becker T \& Di Marzo V 2014 Endocannabinoids and energy homeostasis: an update. BioFactors 40 389-397. (doi:10.1002/ biof.1168)

Dani JA \& Bertrand D 2007 Nicotinic acetylcholine receptors and nicotinic cholinergic mechanisms of the central nervous system. Annual Review of Pharmacology and Toxicology 47 699-729. (doi:10.1146/annurev.pharmtox.47.120505.105214)

De Biasi M \& Dani JA 2011 Reward, addiction, withdrawal to nicotine. Annual Review of Neuroscience 34 105-130. (doi:10.1146/annurevneuro-061010-113734)

De la Fuente IM, Cortés JM, Valero E, Desroches M, Rodrigues S, Malaina I \& Martínez L 2014 On the dynamics of the adenylate energy system: homeorhesis vs homeostasis. PLOS ONE 9 e108676. (doi:10.1371/ journal.pone.0108676)

de Lecea L, Kilduff TS, Peyron C, Gao X, Foye PE, Danielson PE, Fukuhara C, Battenberg EL, Gautvik VT, Bartlett FS 2nd, et al. 1998 The hypocretins: hypothalamus-specific peptides with neuroexcitatory activity. PNAS 95 322-327. (doi:10.1073/pnas.95.1.322)

de Oliveira E, Moura EG, Santos-Silva AP, Pinheiro CR, Lima NS, NogueiraNeto JF, Nunes-Freitas AL, Abreu-Villaca Y, Passos MC \& Lisboa PC 
2010 Neonatal nicotine exposure causes insulin and leptin resistance and inhibits hypothalamic leptin signaling in adult rat offspring. Journal of Endocrinology 206 55-63. (doi:10.1677/JOE-10-0104)

Dezfuli G, Kellar KJ, Dretchen KL, Tizabi Y, Sahibzada N \& Gillis RA 2016 Evidence for the role of beta2* $\mathrm{nAChR}$ desensitization in regulating body weight in obese mice. Neuropharmacology 110 165-174. (doi:10.1016/j.neuropharm.2016.07.020)

Dickson SL, Hrabovszky E, Hansson C, Jerlhag E, Alvarez-Crespo M, Skibicka KP, Molnar CS, Liposits Z, Engel JA \& Egecioglu E 2010 Blockade of central nicotine acetylcholine receptor signaling attenuate ghrelin-induced food intake in rodents. Neuroscience $\mathbf{1 7 1}$ 1180-1186. (doi:10.1016/j.neuroscience.2010.10.005)

Donny EC, Caggiula AR, Weaver MT, Levin ME \& Sved AF 2011 The reinforcement-enhancing effects of nicotine: implications for the relationship between smoking, eating and weight. Physiology and Behavior 104 143-148. (doi:10.1016/j.physbeh.2011.04.043)

Dryden S, Frankish HM, Wang Q, Pickavance L \& Williams G 1996 The serotonergic agent fluoxetine reduces neuropeptide $Y$ levels and neuropeptide $Y$ secretion in the hypothalamus of lean and obese rats. Neuroscience 72 557-566. (doi:10.1016/0306-4522(95)00566-8)

Eliasson B \& Smith U 1999 Leptin levels in smokers and long-term users of nicotine gum. European Journal of Clinical Investigation 29 145-152. (doi:10.1046/j.1365-2362.1999.00420.x)

Ellingsgaard H, Ehses JA, Hammar EB, Van Lommel L, Quintens R, Martens G, Kerr-Conte J, Pattou F, Berney T, Pipeleers D, et al. 2008 Interleukin-6 regulates pancreatic $\alpha$-cell mass expansion. PNAS 105 13163-13168. (doi:10.1073/pnas.0801059105)

Ellingsgaard H, Hauselmann I, Schuler B, Habib AM, Baggio LL, Meier DT, Eppler E, Bouzakri K, Wueest S, Muller YD, et al. 2011 Interleukin-6 enhances insulin secretion by increasing glucagon-like peptide-1 secretion from L cells and alpha cells. Nature Medicine 17 1481-1489. (doi:10.1038/nm.2513)

Enriori PJ, Evans AE, Sinnayah P \& Cowley MA 2006 Leptin resistance and obesity. Obesity 14 (Supplement 5) 254s-258s. (doi:10.1038/ oby.2006.319)

Facchini FS, Hollenbeck CB, Jeppesen J, Chen YD \& Reaven GM 1992 Insulin resistance and cigarette smoking. Lancet 339 1128-1130. (doi:10.1016/0140-6736(92)90730-Q)

Farooqi IS, Bullmore E, Keogh J, Gillard J, O'Rahilly S \& Fletcher PC 2007 Leptin regulates striatal regions and human eating behavior. Science 317 1355. (doi:10.1126/science.1144599)

Fernandez-Real JM, Broch M, Vendrell J \& Ricart W 2003 Smoking, fat mass and activation of the tumor necrosis factor-alpha pathway. International Journal of Obesity and Related Metabolic Disorders 27 1552-1556. (doi:10.1038/sj.ijo.0802472)

Figlewicz DP, Evans SB, Murphy J, Hoen M \& Baskin DG 2003 Expression of receptors for insulin and leptin in the ventral tegmental area/ substantia nigra (VTA/SN) of the rat. Brain Research 964 107-115. (doi:10.1016/S0006-8993(02)04087-8)

Figlewicz DP, Bennett JL, Aliakbari S, Zavosh A \& Sipols AJ 2008 Insulin acts at different CNS sites to decrease acute sucrose intake and sucrose self-administration in rats. American Journal of Physiology Regulatory, Integrative and Comparative Physiology 295 R388-R394. (doi:10.1152/ ajpregu.90334.2008)

Filozof C, Fernández Pinilla MC \& Fernandez-Cruz A 2004 Smoking cessation and weight gain. Obesity Reviews 5 95-103. (doi:10.1111/ j.1467-789X.2004.00131.x)

Ford MM, Fretwell AM, Nickel JD, Mark GP, Strong MN, Yoneyama N \& Finn DA 2009 The influence of mecamylamine on ethanol and sucrose self-administration. Neuropharmacology $\mathbf{5 7} 250-258$. (doi:10.1016/j.neuropharm.2009.05.012)

Frankish HM, Dryden S, Wang Q, Bing C, MacFarlane IA \& Williams G 1995 Nicotine administration reduces neuropeptide $Y$ and neuropeptide Y mRNA concentrations in the rat hypothalamus: NPY may mediate nicotine's effects on energy balance. Brain Research 694 139-146. (doi:10.1016/0006-8993(95)00834-D)
Fride E, Bregman T \& Kirkham TC 2005 Endocannabinoids and food intake: newborn suckling and appetite regulation in adulthood. Experimental Biology and Medicine 230 225-234. (doi:10.1177/153537 020523000401)

Fulton S, Pissios P, Manchon RP, Stiles L, Frank L, Pothos EN, MaratosFlier E \& Flier JS 2006 Leptin regulation of the mesoaccumbens dopamine pathway. Neuron 51 811-822. (doi:10.1016/j. neuron.2006.09.006)

Galindo-Charles L, Hernandez-Lopez S, Galarraga E, Tapia D, Bargas J, Garduno J, Frias-Dominguez C, Drucker-Colin R \& Mihailescu S 2008 Serotoninergic dorsal raphe neurons possess functional postsynaptic nicotinic acetylcholine receptors. Synapse 62 601-615. (doi:10.1002/ syn.20526)

García AP, Aitta-aho T, Schaaf L, Heeley N, Heuschmid L, Bai Y, Barrantes FJ \& Apergis-Schoute J 2015 Nicotinic $\alpha 4$ receptor-mediated cholinergic influences on food intake and activity patterns in hypothalamic circuits. PLOS ONE 10 e0133327. (doi:10.1371/journal.pone.0133327)

Gardner EL 2005 Endocannabinoid signaling system and brain reward: emphasis on dopamine. Pharmacology Biochemistry and Behavior $\mathbf{8 1}$ 263-284. (doi:10.1016/j.pbb.2005.01.032)

Georgescu D, Sears RM, Hommel JD, Barrot M, Bolanos CA, Marsh DJ, Bednarek MA, Bibb JA, Maratos-Flier E, Nestler EJ, et al. 2005 The hypothalamic neuropeptide melanin-concentrating hormone acts in the nucleus accumbens to modulate feeding behavior and forced-swim performance. Journal of Neuroscience 25 2933-2940. (doi:10.1523/JNEUROSCI.1714-04.2005)

Gil-Campos M, Aguilera CM, Canete R \& Gil A 2006 Ghrelin: a hormone regulating food intake and energy homeostasis. British Journal of Nutrition 96 201-226. (doi:10.1079/BJN20061787)

Gill GV, Morgan C \& MacFarlane IA 2005 Awareness and use of smoking cessation treatments among diabetic patients. Diabetic Medicine 22 658-660. (doi:10.1111/j.1464-5491.2005.01471.x)

Glowa JR \& Gold PW 1991 Corticotropin releasing hormone produces profound anorexigenic effects in the rhesus monkey. Neuropeptides $\mathbf{1 8}$ 55-61. (doi:10.1016/0143-4179(91)90164-E)

Gomez G, Lambertz I, Udupi V, Qi X, Thompson JC \& Greeley GH Jr 1996 Influence of nicotine on gastrin and peptide $\mathrm{YY}$ in the rat. Regulatory Peptides 67 55-61. (doi:10.1016/S0167-0115(96)00107-3)

Gonzalez S, Cascio MG, Fernandez-Ruiz J, Fezza F, Di Marzo V \& Ramos JA 2002 Changes in endocannabinoid contents in the brain of rats chronically exposed to nicotine, ethanol or cocaine. Brain Research 954 73-81. (doi:10.1016/S0006-8993(02)03344-9)

Goodman T, Ferro A \& Sharma P 2008 Pharmacogenetics of aspirin resistance: a comprehensive systematic review. British Journal of Clinical Pharmacology 66 222-232. (doi:10.1111/j.1365-2125.2008.03183.x)

Grady S, Marks MJ, Wonnacott S \& Collins AC 1992 Characterization of nicotinic receptor-mediated [3H]dopamine release from synaptosomes prepared from mouse striatum. Journal of Neurochemistry 59 848-856. (doi:10.1111/j.1471-4159.1992.tb08322.x)

Grady SR, Salminen O, Laverty DC, Whiteaker P, McIntosh JM, Collins AC \& Marks MJ 2007 The subtypes of nicotinic acetylcholine receptors on dopaminergic terminals of mouse striatum. Biochemical Pharmacology 74 1235-1246. (doi:10.1016/j.bcp.2007.07.032)

Gropp E, Shanabrough M, Borok E, Xu AW, Janoschek R, Buch T, Plum L, Balthasar N, Hampel B, Waisman A, et al. 2005 Agouti-related peptideexpressing neurons are mandatory for feeding. Nature Neuroscience $\mathbf{8}$ 1289-1291. (doi:10.1038/nn1548)

Hamilton CL, Ciaccia PJ \& Lewis DO 1976 Feeding behavior in monkeys with and without lesions of the hypothalamus. American Journal of Physiology 230 818-830.

Harms M \& Seale P 2013 Brown and beige fat: development, function and therapeutic potential. Nature Medicine 19 1252-1263. (doi:10.1038/ nm.3361)

Harwood HJ Jr 2012 The adipocyte as an endocrine organ in the regulation of metabolic homeostasis. Neuropharmacology 63 57-75. (doi:10.1016/j.neuropharm.2011.12.010) 
Hofstetter A, Schutz Y, Jéquier E \& Wahren J 1986 Increased 24-hour energy expenditure in cigarette smokers. New England Journal of Medicine 314 79-82. (doi:10.1056/NEJM198601093140204)

Hollander JA, Lu Q, Cameron MD, Kamenecka TM \& Kenny PJ 2008 Insular hypocretin transmission regulates nicotine reward. PNAS $\mathbf{1 0 5}$ 19480-19485. (doi:10.1073/pnas.0808023105)

Hommel JD, Trinko R, Sears RM, Georgescu D, Liu ZW, Gao XB, Thurmon JJ, Marinelli M \& DiLeone RJ 2006 Leptin receptor signaling in midbrain dopamine neurons regulates feeding. Neuron $\mathbf{5 1} 801-810$. (doi:10.1016/j.neuron.2006.08.023)

Huang H, Xu Y \& van den Pol AN 2011 Nicotine excites hypothalamic arcuate anorexigenic proopiomelanocortin neurons and orexigenic neuropeptide Y neurons: similarities and differences. Journal of Neurophysiology 106 1191-1202. (doi:10.1152/jn.00740.2010)

Huang YY, Kandel DB, Kandel ER \& Levine A 2013 Nicotine primes the effect of cocaine on the induction of LTP in the amygdala. Neuropharmacology 74 126-134. (doi:10.1016/j. neuropharm.2013.03.031)

Hussain T, Al-Daghri NM, Al-Attas OS, Draz HM, Abd Al-Rahman SH \& Yakout SM 2012 Plasma neuropeptide Y levels relate cigarette smoking and smoking cessation to body weight regulation. Regulatory Peptides 176 22-27. (doi:10.1016/j.regpep.2012.02.005)

Hussmann GP, DeDominicis KE, Turner JR, Yasuda RP, Klehm J, Forcelli PA, Xiao Y, Richardson JR, Sahibzada N, Wolfe BB, et al. 2014 Chronic sazetidine-A maintains anxiolytic effects and slower weight gain following chronic nicotine without maintaining increased density of nicotinic receptors in rodent brain. Journal of Neurochemistry 129 721-731. (doi:10.1111/jnc.12653)

Inoue K, Takeshima F, Kadota K, Yoda A, Tatsuta Y, Nagaura Y, Yoshioka S, Nakamichi S, Nakao K \& Ozono Y 2011 Early effects of smoking cessation and weight gain on plasma adiponectin levels and insulin resistance. Internal Medicine 50 707-712. (doi:10.2169/ internalmedicine.50.4600)

Jerlhag E, Egecioglu E, Dickson SL, Andersson M, Svensson L \& Engel JA 2006 Ghrelin stimulates locomotor activity and accumbal dopamineoverflow via central cholinergic systems in mice: implications for its involvement in brain reward. Addiction Biology 11 45-54. (doi:10.1111/j.1369-1600.2006.00002.x)

Jo YH, Talmage DA \& Role LW 2002 Nicotinic receptor-mediated effects on appetite and food intake. Journal of Neurobiology 53 618-632. (doi:10.1002/neu.10147)

Jones IW \& Wonnacott S 2004 Precise localization of alpha7 nicotinic acetylcholine receptors on glutamatergic axon terminals in the rat ventral tegmental area. Journal of Neuroscience 24 11244-11252. (doi:10.1523/JNEUROSCI.3009-04.2004)

Jones S, Sudweeks S, \& Yakel JL 1999 Nicotinic receptors in the brain: correlating physiology with function. Trends in Neuroscience 22 555-561. (doi:10.1016/S0166-2236(99)01471-X)

Kadowaki T, Yamauchi T, Kubota N, Hara K, Ueki K \& Tobe K 2006 Adiponectin and adiponectin receptors in insulin resistance, diabetes, and the metabolic syndrome. Journal of Clinical Investigation 116 1784-1792. (doi:10.1172/JCI29126)

Kahn BB, Alquier T, Carling D \& Hardie DG 2005 AMP-activated protein kinase: ancient energy gauge provides clues to modern understanding of metabolism. Cell Metabolism 1 15-25. (doi:10.1016/j. cmet.2004.12.003)

Kane JK, Parker SL \& Li MD 2001 Hypothalamic orexin-A binding sites are downregulated by chronic nicotine treatment in the rat. Neuroscience Letters 298 1-4. (doi:10.1016/S0304-3940(00)01730-4)

Karlsson C, Rehman F, Damdazic R, Atkins AL, Schank JR, Gehlert DR, Steensland P, Thorsell A \& Heilig M 2016 The melanin-concentrating hormone-1 receptor modulates alcohol-induced reward and DARPP-32 phosphorylation. Psychopharmacology 233 2355-2363. (doi:10.1007/s00213-016-4285-y)

Kelley AE \& Berridge KC 2002 The neuroscience of natural rewards: relevance to addictive drugs. Journal of Neuroscience 22 3306-3311.

http://joe.endocrinology-journals.org

DOI: $10.1530 / \mathrm{JOE}-17-0166$
(C) 2017 Society for Endocrinology Printed in Great Britain
Kenny PJ 2011a Common cellular and molecular mechanisms in obesity and drug addiction. Nature Reviews Neuroscience 12 638-651. (doi:10.1038/nrn3105)

Kenny PJ $2011 b$ Reward mechanisms in obesity: new insights and future directions. Neuron 69 664-679. (doi:10.1016/j.neuron.2011.02.016)

Kenny PJ \& Markou A 2006 Nicotine self-administration acutely activates brain reward systems and induces a long-lasting increase in reward sensitivity. Neuropsychopharmacology 31 1203-1211.

Kershaw EE \& Flier JS 2004 Adipose tissue as an endocrine organ. Journal of Clinical Endocrinology and Metabolism 89 2548-2556.

Kim JH, Shim KW KW, Yoon YS, Lee SY, Kim SS \& Oh SW 2012 Cigarette smoking increases abdominal and visceral obesity but not overall fatness: an observational study. PLoS ONE 7 e45815. (doi:10.1371/ journal.pone.0045815)

Klink R, de Kerchove d'Exaerde A, Zoli M \& Changeux JP 2001 Molecular and physiological diversity of nicotinic acetylcholine receptors in the midbrain dopaminergic nuclei. Journal of Neuroscience 21 1452-1463.

Kobeissy FH, Jeung JA, Warren MW, Geier JE \& Gold MS 2008 Changes in leptin, ghrelin, growth hormone and neuropeptide-Y after an acute model of MDMA and methamphetamine exposure in rats. Addiction Biology 13 15-25. (doi:10.1111/j.1369-1600.2007.00083.x)

Kokkinos A, Tentolouris N, Kyriakaki E, Argyrakopoulou G, Doupis J, Psallas M, Kyriaki D \& Katsilambros N 2007 Differentiation in the short- and long-term effects of smoking on plasma total ghrelin concentrations between male nonsmokers and habitual smokers. Metabolism 56 523-527. (doi:10.1016/j.metabol.2006.11.012)

Konner AC, Hess S, Tovar S, Mesaros A, Sanchez-Lasheras C, Evers N, Verhagen LA, Bronneke HS, Kleinridders A, Hampel B, et al. 2011 Role for insulin signaling in catecholaminergic neurons in control of energy homeostasis. Cell Metabolism 13 720-728. (doi:10.1016/j. cmet.2011.03.021)

Koob GF, Sanna PP \& Bloom FE 1998 Neuroscience of addiction. Neuron 21 467-476. (doi:10.1016/S0896-6273(00)80557-7)

Kotagale NR, Walke S, Shelkar GP, Kokare DM, Umekar MJ \& Taksande BG 2014 Agmatine attenuates nicotine induced conditioned place preference in mice through modulation of neuropeptide $\mathrm{Y}$ system. Behavioural Brain Research 262 118-124. (doi:10.1016/j. bbr.2014.01.004)

Kubota N, Yano W, Kubota T, Yamauchi T, Itoh S, Kumagai H, Kozono H, Takamoto I, Okamoto S, Shiuchi T, et al. 2007 Adiponectin stimulates AMP-activated protein kinase in the hypothalamus and increases food intake. Cell Metabolism 6 55-68. (doi:10.1016/j. cmet.2007.06.003)

Le Foll B \& Goldberg SR 2004 Rimonabant, a CB1 antagonist, blocks nicotine-conditioned place preferences. Neuroreport 15 2139-2143. (doi:10.1097/00001756-200409150-00028)

Lee H, Joe KH, Kim W, Park J, Lee DH, Sung KW \& Kim DJ 2006 Increased leptin and decreased ghrelin level after smoking cessation. Neuroscience Letters 409 47-51. (doi:10.1016/j.neulet.2006.09.013)

Lehrke M, Reilly MP, Millington SC, Iqbal N, Rader DJ \& Lazar MA 2004 An inflammatory cascade leading to hyperresistinemia in humans. PLoS Medicine 1 e45. (doi:10.1371/journal.pmed.0010045)

Leibowitz SF \& Alexander JT 1998 Hypothalamic serotonin in control of eating behavior, meal size, and body weight. Biological Psychiatry 44 851-864. (doi:10.1016/S0006-3223(98)00186-3)

Lenard NR \& Berthoud HR 2008 Central and peripheral regulation of food intake and physical activity: pathways and genes. Obesity 16 (Supplement 3) S11-S22. (doi:10.1038/oby.2008.511)

LeSage MG, Perry JL, Kotz CM, Shelley D \& Corrigall WA 2010 Nicotine self-administration in the rat: effects of hypocretin antagonists and changes in hypocretin mRNA. Psychopharmacology 209 203-212. (doi:10.1007/s00213-010-1792-0)

Li MD \& Kane JK 2003 Effect of nicotine on the expression of leptin and forebrain leptin receptors in the rat. Brain Research $991222-231$. (doi:10.1016/j.brainres.2003.08.024) 
Liu R-H, Mizuta M \& Matsukura S 2003 Long-term oral nicotine administration reduces insulin resistance in obese rats. European Journal of Pharmacology 458 227-234. (doi:10.1016/S00142999(02)02726-7)

Liu R-H, Mizuta M \& Matsukura S 2004 The expression and functional role of nicotinic acetylcholine receptors in rat adipocytes. Journal of Pharmacology and Experimental Therapeutics 310 52-58. (doi:10.1124/ jpet.103.065037)

Lopez M, Lage R, Saha AK, Perez-Tilve D, Vazquez MJ, Varela L, SangiaoAlvarellos S, Tovar S, Raghay K, Rodriguez-Cuenca S, et al. 2008 Hypothalamic fatty acid metabolism mediates the orexigenic action of ghrelin. Cell Metabolism 7 389-399. (doi:10.1016/j. cmet.2008.03.006)

Lowell BB \& Spiegelman BM 2000 Towards a molecular understanding of adaptive thermogenesis. Nature $\mathbf{4 0 4} 652-660$.

Lupien JR \& Bray GA 1988 Nicotine increases thermogenesis in brown adipose tissue in rats. Pharmacology Biochemistry and Behavior 29 33-37. (doi:10.1016/0091-3057(88)90269-9)

Lutter M \& Nestler EJ 2009 Homeostatic and hedonic signals interact in the regulation of food intake. Journal of Nutrition 139 629-632. (doi:10.3945/jn.108.097618)

Maldonado R, Valverde O \& Berrendero F 2006 Involvement of the endocannabinoid system in drug addiction. Trends in Neurosciences 29 225-232. (doi:10.1016/j.tins.2006.01.008)

Mangubat M, Lutfy K, Lee ML, Pulido L, Stout D, Davis R, Shin CS, Shahbazian M, Seasholtz S, Sinha-Hikim A, et al. 2012 Effect of nicotine on body composition in mice. Journal of Endocrinology 212 317-326. (doi:10.1530/JOE-11-0350)

Mao D, Yasuda RP, Fan H, Wolfe BB \& Kellar KJ 2006 Heterogeneity of nicotinic cholinergic receptors in rat superior cervical and nodose ganglia. Molecular Pharmacology 70 1693-1699. (doi:10.1124/ mol.106.027458)

Mark GP, Shabani S, Dobbs LK \& Hansen ST 2011 Cholinergic modulation of mesolimbic dopamine function and reward. Physiology and Behavior 104 76-81. (doi:10.1016/j.physbeh.2011.04.052)

Marrero MB, Lucas R, Salet C, Hauser TA, Mazurov A, Lippiello PM \& Bencherif M 2010 An alpha7 nicotinic acetylcholine receptor-selective agonist reduces weight gain and metabolic changes in a mouse model of diabetes. Journal of Pharmacology and Experimental Therapeutics 332 173-180. (doi:10.1124/jpet.109.154633)

Martinez de Morentin PB, Whittle AJ, Ferno J, Nogueiras R, Dieguez C, Vidal-Puig A \& Lopez M 2012 Nicotine induces negative energy balance through hypothalamic AMP-activated protein kinase. Diabetes 61 807-817. (doi:10.2337/db11-1079)

Matsuzawa Y 2006 The metabolic syndrome and adipocytokines. FEBS Letters 580 2917-2921. (doi:10.1016/j.febslet.2006.04.028)

McGehee DS, Heath MJ, Gelber S, Devay P \& Role LW 1995 Nicotine enhancement of fast excitatory synaptic transmission in CNS by presynaptic receptors. Science 269 1692-1696. (doi:10.1126/ science.7569895)

Mebel DM, Wong JC, Dong YJ \& Borgland SL 2012 Insulin in the ventral tegmental area reduces hedonic feeding and suppresses dopamine concentration via increased reuptake. European Journal of Neuroscience 36 2336-2346. (doi:10.1111/j.14609568.2012.08168.x)

Meguid MM, Fetissov SO, Varma M, Sato T, Zhang L, Laviano A \& Rossi-Fanelli F 2000 Hypothalamic dopamine and serotonin in the regulation of food intake. Nutrition 16 843-857. (doi:10.1016/S08999007(00)00449-4)

Meister B 2000 Control of food intake via leptin receptors in the hypothalamus. Vitamins and Hormones 59 265-304.(doi:10.1016/ s0083-6729(00)59010-4)

Mineur YS, Abizaid A, Rao Y, Salas R, DiLeone RJ, Gündisch D, Diano S, De Biasi M, Horvath TL, Gao XB, et al. 2011 Nicotine decreases food intake through activation of POMC neurons. Science 332 1330-1332. (doi:10.1126/science.1201889)
Minokoshi Y, Alquier T, Furukawa N, Kim YB, Lee A, Xue B, Mu J, Foufelle F, Ferre P, Birnbaum MJ, et al. 2004 AMP-kinase regulates food intake by responding to hormonal and nutrient signals in the hypothalamus. Nature 428 569-574. (doi:10.1038/nature02440)

Morgan TM, Crawford L, Stoller A, Toth D, Yeo K-TJ \& Baron JA 2004 Acute effects of nicotine on serum glucose insulin growth hormone and cortisol in healthy smokers. Metabolism 53 578-582. (doi:10.1016/j.metabol.2003.12.006)

Murray S, Tulloch A, Gold MS \& Avena NM 2014 Hormonal and neural mechanisms of food reward, eating behaviour and obesity. Nature Reviews Endocrinology 10 540-552. (doi:10.1038/ nrendo.2014.91)

Murzi E, Contreras Q, Teneud L, Valecillos B, Parada MA, De Parada MP \& Hernandez L 1996 Diabetes decreases limbic extracellular dopamine in rats. Neuroscience Letters 202 141-144. (doi:10.1016/03043940(95)12232-X)

Myers MG \& Olson DP 2012 Central nervous system control of metabolism. Nature 491 357-363. (doi:10.1038/nature11705)

Naleid AM, Grace MK, Cummings DE \& Levine AS 2005 Ghrelin induces feeding in the mesolimbic reward pathway between the ventral tegmental area and the nucleus accumbens. Peptides 26 2274-2279. (doi:10.1016/j.peptides.2005.04.025)

Naude J, Tolu S, Dongelmans M, Torquet N, Valverde S, Rodriguez G, Pons S, Maskos U, Mourot A, Marti F, et al. 2016 Nicotinic receptors in the ventral tegmental area promote uncertainty-seeking. Nature Neuroscience 19 471-478. (doi:10.1038/nn.4223)

Nestler EJ 2005 Is there a common molecular pathway for addiction? Nature Neuroscience 8 1445-1449. (doi:10.1038/nn1578)

Niswender KD, Morrison CD, Clegg DJ, Olson R, Baskin DG, Myers MG, Seeley RJ \& Schwartz MW 2003 Insulin activation of phosphatidylinositol 3-Kinase in the hypothalamic arcuate nucleus. A Key Mediator of Insulin-Induced Anorexia 52 227-231.(doi:10.2337/ diabetes.52.2.227)

O'Dell LE, Natividad LA, Pipkin JA, Roman F, Torres I, Jurado J, Torres OV, Friedman TC, Tenayuca JM \& Nazarian A 2014 Enhanced nicotine self-administration and suppressed dopaminergic systems in a rat model of diabetes. Addiction Biology 19 1006-1019. (doi:10.1111/ adb.12074)

O'Hara BF, Edgar DM, Cao VH, Wiler SW, Heller HC, Kilduff TS \& Miller JD 1998 Nicotine and nicotinic receptors in the circadian system. Psychoneuroendocrinology 23 161-173. (doi:10.1016/s03064530(97)00077-2)

Oliveira-Maia AJ, Stapleton-Kotloski JR, Lyall V, Phan T-HT, Mummalaneni S, Melone P, DeSimone JA, Nicolelis MAL \& Simon SA 2009 Nicotine activates TRPM5-dependent and independent taste pathways. PNAS 106 1596-1601. (doi:10.1073/pnas.0810184106)

Ostlund SB, Kosheleff AR \& Maidment NT 2014 Differential effects of systemic cholinergic receptor blockade on Pavlovian incentive motivation and goal-directed action selection. Neuropsychopharmacology 39 1490-1497. (doi:10.1038/ npp.2013.348)

Parker LA \& Doucet K 1995 The effects of nicotine and nicotine withdrawal on taste reactivity. Pharmacology Biochemistry and Behavior 52 125-129. (doi:10.1016/0091-3057(95)00060-A)

Pavlov VA, Wang H, Czura CJ, Friedman SG \& Tracey KJ 2003 The cholinergic anti-inflammatory pathway: a missing link in neuroimmunomodulation. Molecular Medicine 9 125-134.

Perkins KA 1992 Metabolic effects of cigarette smoking. Journal of Applied Physiology 72 401-409.

Piomelli D 2003 The molecular logic of endocannabinoid signalling. Nature Reviews Neuroscience 4 873-884. (doi:10.1038/nrn1247)

Plum L, Belgardt BF \& Bruning JC 2006 Central insulin action in energy and glucose homeostasis. Journal of Clinical Investigation 116 1761-1766. (doi:10.1172/JCI29063)

Porter C 2017 Quantification of UCP1 function in human brown adipose tissue. Adipocyte 1-8. 
Qi Y, Takahashi N, Hileman SM, Patel HR, Berg AH, Pajvani UB, Scherer PE \& Ahima RS 2004 Adiponectin acts in the brain to decrease body weight. Nature Medicine 10 524-529. (doi:10.1038/nm1029)

Qu D, Ludwig DS, Gammeltoft S, Piper M, Pelleymounter MA, Cullen MJ Mathes WF, Przypek R, Kanarek R \& Maratos-Flier E 1996 A role for melanin-concentrating hormone in the central regulation of feeding behaviour. Nature 380 243-247. (doi:10.1038/380243a0)

Ramos EJ, Meguid MM, Campos AC \& Coelho JC 2005 Neuropeptide Y, alpha-melanocyte-stimulating hormone, and monoamines in food intake regulation. Nutrition 21 269-279. (doi:10.1016/j.nut.2004.06.021)

Richardson JR, Pipkin JA, O'Dell LE \& Nazarian A 2014 Insulin resistant rats display enhanced rewarding effects of nicotine. Drug Alcohol Depend 140 205-207. (doi:10.1016/j.drugalcdep.2014.03.028)

Rinaman L 2010 Ascending projections from the caudal visceral nucleus of the solitary tract to brain regions involved in food intake and energy expenditure. Brain Research 1350 18-34. (doi:10.1016/j. brainres.2010.03.059)

Risner ME \& Goldberg SR 1983 A comparison of nicotine and cocaine self-administration in the dog: fixed-ratio and progressive-ratio schedules of intravenous drug infusion. Journal of Pharmacology and Experimental Therapeutics 224 319-326.

Rohleder N \& Kirschbaum C 2006 The hypothalamic-pituitaryadrenal (HPA) axis in habitual smokers. International Journal of Psychophysiology 59 236-243. (doi:10.1016/j.ijpsycho.2005.10.012)

Rubinstein M, Mogil JS, Japon M, Chan EC, Allen RG \& Low MJ 1996 Absence of opioid stress-induced analgesia in mice lacking betaendorphin by site-directed mutagenesis. PNAS 93 3995-4000. (doi:10.1073/pnas.93.9.3995)

Rupprecht LE, Donny EC \& Sved AF 2015 Obese smokers as a potential subpopulation of risk in tobacco reduction policy. Yale Journal of Biology and Medicine 88 289-294.

Rusk IN \& Cooper SJ 1989 The selective dopamine D1 receptor agonist SK\&F 38393: its effects on palatability- and deprivation-induced feeding, and operant responding for food. Pharmacology Biochemistry and Behavior 34 17-22. (doi:10.1016/0091-3057(89)90346-8)

Sam AH, Troke RC, Tan TM \& Bewick GA 2012 The role of the gut/ brain axis in modulating food intake. Neuropharmacology 63 46-56. (doi:10.1016/j.neuropharm.2011.10.008)

Scherer PE, Williams S, Fogliano M, Baldini G \& Lodish HF 1995 A novel serum protein similar to C1q, produced exclusively in adipocytes. Journal of Biological Chemistry 270 26746-26749. (doi:10.1074/ jbc.270.45.26746)

Schilstrom B, Svensson HM, Svensson TH \& Nomikos GG 1998 Nicotine and food induced dopamine release in the nucleus accumbens of the rat: putative role of alpha7 nicotinic receptors in the ventral tegmental area. Neuroscience 85 1005-1009. (doi:10.1016/S03064522(98)00114-6)

Schilstrom B, Fagerquist MV, Zhang X, Hertel P, Panagis G, Nomikos GG \& Svensson TH 2000 Putative role of presynaptic alpha7* nicotinic receptors in nicotine stimulated increases of extracellular levels of glutamate and aspartate in the ventral tegmental area. Synapse 38 375-383. (doi:10.1002/1098-2396(20001215)38:4\&lt;375::AIDSYN2\&gt;3.0.CO;2-Y)

Schwartz MW, Woods SC, Porte D Jr, Seeley RJ \& Baskin DG 2000 Central nervous system control of food intake. Nature $\mathbf{4 0 4} 661-671$. (doi:10.1038/35007534)

Seguela P, Wadiche J, Dineley-Miller K, Dani JA \& Patrick JW 1993 Molecular cloning, functional properties, and distribution of rat brain alpha 7: a nicotinic cation channel highly permeable to calcium. Journal of Neuroscience 13 596-604.

Seoane-Collazo P, Martinez de Morentin PB, Ferno J, Dieguez C, Nogueiras R \& Lopez M 2014 Nicotine improves obesity and hepatic steatosis and ER stress in diet-induced obese male rats. Endocrinology 155 1679-1689. (doi:10.1210/en.2013-1839)

Shariff M, Quik M, Holgate J, Morgan M, Patkar OL, Tam V, Belmer A \& Bartlett SE 2016 Neuronal nicotinic acetylcholine receptor modulators reduce sugar intake. PLOS ONE 11 e0150270. (doi:10.1371/journal. pone.0150270)

Skibicka KP, Hansson C, Alvarez-Crespo M, Friberg PA \& Dickson SL 2011 Ghrelin directly targets the ventral tegmental area to increase food motivation. Neuroscience 180 129-137. (doi:10.1016/j. neuroscience.2011.02.016)

Skofitsch G, Jacobowitz DM \& Zamir N 1985 Immunohistochemical localization of a melanin concentrating hormone-like peptide in the rat brain. Brain Research Bulletin 15 635-649. (doi:10.1016/03619230(85)90213-8)

Sleight AJ, Carolo C, Petit N, Zwingelstein C \& Bourson A 1995 Identification of 5-hydroxytryptamine7 receptor binding sites in rat hypothalamus: sensitivity to chronic antidepressant treatment. Molecular Pharmacology 47 99-103.

Smart JL \& Low MJ 2003 Lack of proopiomelanocortin peptides results in obesity and defective adrenal function but normal melanocyte pigmentation in the murine C57BL/6 genetic background. Annals of the New York Academy of Sciences 994 202-210. (doi:10.1111/j.1749-6632.2003.tb03181.x)

Solberg LI, Desai JR, O'Connor PJ, Bishop DB \& Devlin HM 2004 Diabetic patients who smoke: are they different? Annals of Family Medicine $\mathbf{2}$ 26-32. (doi:10.1370/afm.36)

Solinas M, Goldberg SR \& Piomelli D 2008 The endocannabinoid system in brain reward processes. British Journal of Pharmacology 154 369-383. (doi:10.1038/bjp.2008.130)

Spring B, Pagoto S, McChargue D, Hedeker D \& Werth J 2003 Altered reward value of carbohydrate snacks for female smokers withdrawn from nicotine. Pharmacology Biochemistry and Behavior 76 351-360. (doi:10.1016/j.pbb.2003.08.008)

Stamford BA, Matter S, Fell RD \& Papanek P 1986 Effects of smoking cessation on weight gain, metabolic rate, caloric consumption, and blood lipids. American Journal of Clinical Nutrition 43 486-494.

Stanley BG, Willett VL 3rd, Donias HW, Ha LH \& Spears LC 1993 The lateral hypothalamus: a primary site mediating excitatory amino acid-elicited eating. Brain Research 630 41-49. (doi:10.1016/00068993(93)90640-9)

Summers KL \& Giacobini E 1995 Effects of local and repeated systemic administration of (-)nicotine on extracellular levels of acetylcholine, norepinephrine, dopamine, and serotonin in rat cortex. Neurochemical Research 20 753-759. (doi:10.1007/ BF01705545)

Suzuki K, Simpson KA, Minnion JS, Shillito JC \& Bloom SR 2010 The role of gut hormones and the hypothalamus in appetite regulation. Endocrine Journal 57 359-372. (doi:10.1507/endocrj.K10E-077)

Tanaka C, Asakawa A, Ushikai M, Sakoguchi T, Amitani H, Terashi M, Cheng K, Chaolu H, Nakamura N \& Inui A 2009 Comparison of the anorexigenic activity of CRF family peptides. Biochemical and Biophysical Research Communications 390 887-891. (doi:10.1016/j. bbrc.2009.10.069)

Tracey KJ 2007 Physiology and immunology of the cholinergic antiinflammatory pathway. Journal of Clinical Investigation $\mathbf{1 1 7}$ 289-296. (doi:10.1172/JCI30555)

Trayhurn P \& Wood IS 2004 Adipokines: inflammation and the pleiotropic role of white adipose tissue. British Journal of Nutrition 92 347-355. (doi:10.1079/BJN20041213)

Trigo JM, Zimmer A \& Maldonado R 2009 Nicotine anxiogenic and rewarding effects are decreased in mice lacking betaendorphin. Neuropharmacology 56 1147-1153. (doi:10.1016/j. neuropharm.2009.03.013)

Tweed JO, Hsia SH, Lutfy K \& Friedman TC 2012 The endocrine effects of nicotine and cigarette smoke. Trends in Endocrinology and Metabolism 23 334-342. (doi:10.1016/j.tem.2012.03.006)

Uehara Y, Shimizu H, Ohtani K, Sato N \& Mori M 1998 Hypothalamic corticotropin-releasing hormone is a mediator of the anorexigenic effect of leptin. Diabetes 47 890-893. (doi:10.2337/ diabetes.47.6.890) 
Vaisse C, Halaas JL, Horvath CM, Darnell JE, Stoffel M \& Friedman JM 1996 Leptin activation of Stat3 in the hypothalamus of wild-type and ob/ob mice but not db/db mice. Nature Genetics 14 95-97. (doi:10.1038/ng0996-95)

Valassi E, Scacchi M \& Cavagnini F 2008 Neuroendocrine control of food intake. Nutrition, Metabolism and Cardiovascular Diseases 18 158-168. (doi:10.1016/j.numecd.2007.06.004)

Van Bockstaele EJ, Peoples J, Menko AS, McHugh K \& Drolet G 2000 Decreases in endogenous opioid peptides in the rat medullo-coerulear pathway after chronic morphine treatment. Journal of Neuroscience $\mathbf{2 0}$ 8659-8666.

Volkow ND, Wang GJ, Fowler JS \& Telang F 2008 Overlapping neuronal circuits in addiction and obesity: evidence of systems pathology. Philosophical Transactions of the Royal Society of London 363 3191-3200. (doi:10.1098/rstb.2008.0107)

Vosselman MJ, van Marken Lichtenbelt WD \& Schrauwen P 2013 Energy dissipation in brown adipose tissue: from mice to men. Molecular and Cellular Endocrinology 379 43-50. (doi:10.1016/j.mce.2013.04.017)

Wada E, Wada K, Boulter J, Deneris E, Heinemann S, Patrick J \& Swanson LW 1989 Distribution of alpha 2, alpha 3, alpha 4, and beta 2 neuronal nicotinic receptor subunit mRNAs in the central nervous system: a hybridization histochemical study in the rat. Journal of Comparative Neurology 284 314-335. (doi:10.1002/cne.902840212)

Wager-Srdar SA, Levine AS, Morley JE, Hoidal JR \& Niewoehner DE 1984 Effects of cigarette smoke and nicotine on feeding and energy. Physiology and Behavior 32 389-395. (doi:10.1016/0031-9384(84)90252-X)

Waldbillig RJ, Bartness TJ \& Stanley BG 1981 Increased food intake, body weight, and adiposity in rats after regional neurochemical depletion of serotonin. Journal of Comparative and Physiological Psychology 95 391-405. (doi:10.1037/h0077790)

Wang H, Yu M, Ochani M, Amella CA, Tanovic M, Susarla S, Li JH, Wang H, Yang H, Ulloa L, et al. 2003 Nicotinic acetylcholine receptor [alpha]7 subunit is an essential regulator of inflammation. Nature 421 384-388. (doi:10.1038/nature01339)

Weisberg SP, McCann D, Desai M, Rosenbaum M, Leibel RL \& Ferrante AW 2003 Obesity is associated with macrophage accumulation in adipose tissue. Journal of Clinical Investigation 112 1796-1808. (doi:10.1172/JCI200319246)

Wellman PJ, Marmon MM, Reich S \& Ruddle J 1986 Effects of nicotine on body weight, food intake and brown adipose tissue thermogenesis. Pharmacology Biochemistry and Behavior 24 1605-1609. (doi:10.1016/0091-3057(86)90493-4)

Wisse BE 2004 The inflammatory syndrome: the role of adipose tissue cytokines in metabolic disorders linked to obesity. Journal of the American Society of Nephrology 15 2792-2800. (doi:10.1097/01. ASN.0000141966.69934.21)

Won W-Y, Lee C-U, Chae J-H, Kim J-J, Lee C \& Kim D-J 2014 Changes of plasma adiponectin levels after smoking cessation. Psychiatry Investigation 11 173-178. (doi:10.4306/pi.2014.11.2.173)

Woods SC \& D'Alessio DA 2008 Central control of body weight and appetite. Journal of Clinical Endocrinology and Metabolism 93 s37-s50. (doi:10.1210/jc.2008-1630)

Wren AM \& Bloom SR 2007 Gut hormones and appetite control. Gastroenterology 132 2116-2130. (doi:10.1053/j.gastro.2007.03.048)

Wu Y, Song P, Zhang W, Liu J, Dai X, Liu Z, Lu Q, Ouyang C, Xie Z, Zhao Z, et al. 2015 Activation of AMPK $\alpha 2$ in adipocytes is essential for nicotine-induced insulin resistance in vivo. Nature Medicine 21 373-382. (doi:10.1038/nm.3826)

Xiao Y, Fan H, Musachio JL, Wei ZL, Chellappan SK, Kozikowski AP \& Kellar KJ 2006 Sazetidine-A, a novel ligand that desensitizes alpha4beta2 nicotinic acetylcholine receptors without activating them. Molecular Pharmacology 70 1454-1460. (doi:10.1124/ mol.106.027318)

Xu T-Y, Guo L-L, Wang P, Song J, Le Y-Y, Viollet B \& Miao C-Y 2012 Chronic exposure to nicotine enhances insulin sensitivity through $\alpha 7$ nicotinic acetylcholine receptor-STAT3 pathway. PLOS ONE 7 e51217. (doi:10.1371/journal.pone.0051217)

Yamauchi T, Kamon J, Waki H, Terauchi Y, Kubota N, Hara K, Mori Y, Ide T, Murakami K, Tsuboyama-Kasaoka N, et al. 2001 The fatderived hormone adiponectin reverses insulin resistance associated with both lipoatrophy and obesity. Nature Medicine 7 941-946. (doi:10.1038/90984)

Yamauchi T, Nio Y, Maki T, Kobayashi M, Takazawa T, Iwabu M, OkadaIwabu M, Kawamoto S, Kubota N, Kubota T, et al. 2007 Targeted disruption of AdipoR1 and AdipoR2 causes abrogation of adiponectin binding and metabolic actions. Nature Medicine 13 332-339. (doi:10.1038/nm1557)

Yoshida T, Yoshioka K, Hiraoka N \& Kondo M 1990 Effect of nicotine on norepinephrine turnover and thermogenesis in brown adipose tissue and metabolic rate in MSG obese mice. Journal of Nutritional Science and Vitaminology 36 123-130. (doi:10.3177/jnsv.36.123)

Yoshida T, Sakane N, Umekawa T, Kogure A, Kondo M, Kumamoto K, Kawada T, Nagase I \& Saito M 1999 Nicotine induces uncoupling protein 1 in white adipose tissue of obese mice. International Journal of Obesity and Related Metabolic Disorders 23 570-575. (doi:10.1038/ sj.ijo.0800870)

Zahniser NR, Goens MB, Hanaway PJ \& Vinych JV 1984 Characterization and regulation of insulin receptors in rat brain. Journal of Neurochemistry 42 1354-1362. (doi:10.1111/j.1471-4159.1984. tb02795.x)

Zhan C, Zhou J, Feng Q, Zhang J-e, Lin S, Bao J, Wu P \& Luo M 2013 Acute and long-term suppression of feeding behavior by POMC neurons in the brainstem and hypothalamus, respectively. Journal of Neuroscience 33 3624-3632. (doi:10.1523/JNEUROSCI.2742-12.2013)

Zhang J \& Berg DK 2007 Reversible inhibition of GABA(A) receptors by $\alpha 7$-containing nicotinic receptors on the vertebrate postsynaptic neurons. Journal of Physiology 579 753-763. (doi:10.1113/ jphysiol.2006.124578)

Zheng H, Patterson LM \& Berthoud HR 2007 Orexin signaling in the ventral tegmental area is required for high-fat appetite induced by opioid stimulation of the nucleus accumbens. Journal of Neuroscience 27 11075-11082. (doi:10.1523/JNEUROSCI.3542-07.2007)

Zhu X, Ottenheimer D \& DiLeone RJ 2016 Activity of D1/2 receptor expressing neurons in the nucleus accumbens regulates running, locomotion, and food intake. Frontiers in Behavioral Neuroscience 10 66. (doi:10.3389/fnbeh.2016.00066)

Zoli M \& Picciotto MR 2012 Nicotinic regulation of energy homeostasis. Nicotine and Tobacco Research 14 1270-1290. (doi:10.1093/ntr/nts159)

Zoli M, Moretti M, Zanardi A, McIntosh JM, Clementi F \& Gotti C 2002 Identification of the nicotinic receptor subtypes expressed on dopaminergic terminals in the rat striatum. Journal of Neuroscience 22 8785-8789.

Received in final form 18 June 2017

Accepted 17 July 2017 http://joe.endocrinology-journals.org
DOI: $10.1530 /$ JOE-17-0166
() 2017 Society for Endocrinology Printed in Great Britain
Published by Bioscientifica Ltd. 